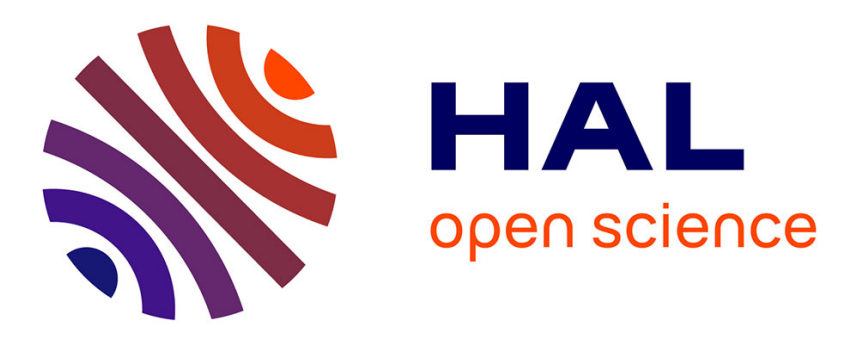

\title{
Activation of the MKL1/actin signaling pathway induces hormonal escape in estrogen-responsive breast cancer cell lines.
}

Gwenneg Kerdivel, Antoine Boudot, Denis Habauzit, Frederic Percevault, Florence Demay, Farzad Pakdel, Gilles Flouriot

\section{To cite this version:}

Gwenneg Kerdivel, Antoine Boudot, Denis Habauzit, Frederic Percevault, Florence Demay, et al.. Activation of the MKL1/actin signaling pathway induces hormonal escape in estrogenresponsive breast cancer cell lines.. Molecular and Cellular Endocrinology, 2014, 390 (1-2), pp.34-44. 10.1016/j.mce.2014.03.009 . hal-01061363

HAL Id: hal-01061363

https://hal-univ-rennes1.archives-ouvertes.fr/hal-01061363

Submitted on 5 Sep 2014

HAL is a multi-disciplinary open access archive for the deposit and dissemination of scientific research documents, whether they are published or not. The documents may come from teaching and research institutions in France or abroad, or from public or private research centers.
L'archive ouverte pluridisciplinaire HAL, est destinée au dépôt et à la diffusion de documents scientifiques de niveau recherche, publiés ou non, émanant des établissements d'enseignement et de recherche français ou étrangers, des laboratoires publics ou privés. 
1 Title: Activation of the MKL1/actin signaling pathway induces hormonal escape in estrogen2 responsive breast cancer cell lines.

3

4 Authors: Gwenneg Kerdivel ${ }^{1}$, Antoine Boudot ${ }^{1}$, Denis Habauzit ${ }^{1}$, Frederic Percevault ${ }^{1}$, Florence 5 Demay $^{1}$, Farzad Pakdel ${ }^{1}$, Gilles Flouriot ${ }^{1 *}$

6

$7 \quad{ }^{1}$ University of Rennes 1, Institut de Recherche en Santé Environnement et Travail, IRSET, INSERM

8 U1085, Team TREC, Biosit, Rennes, France

9

10 *Corresponding author:

11 Dr. Gilles Flouriot

12 INSERM U1085, IRSET, University of Rennes 1, Beaulieu Campus, 35042 Rennes cedex, France.

13 Phone: +33-2 23236804

$14 \quad$ Fax: +33-2 23236794

15 E-mail: gilles.flouriot@univ-rennes1.fr

16

17 Disclosure Statement: The authors have nothing to disclose.

18 


\section{$1 \quad$ Abstract}

2

4 almost $70 \%$ of ER $\alpha$-positive tumors respond to anti-hormone therapies. Unfortunately, during cancer

which have undergone epithelial-mesenchymal transition. We showed that MKL1 activation in MCF-7

11 cells, either by modulating actin dynamics or using MKL1 mutants, down-regulates ER $\alpha$ expression and abolishes E2-dependent cell growth. Interestingly, the constitutively active form of MKL1 represses PR and HER2 expression in these cells and increases the expression of HB-EGF, TGF $\beta$, and

14 amphiregulin growth factors in an E2-independent manner. The resulting expression profile (ER-, PR-, HER2-) typically corresponds to the triple-negative breast cancer expression profile.

16

17 Keywords: MKL1, hormone resistance, breast cancer, cell growth, estrogen receptor, tamoxifen 
Estrogens, especially $17 \beta$-estradiol (E2), control the proliferation and differentiation of the epithelial cells of the mammary gland (Couse and Korach, 1999). The effects of E2 are principally mediated by the estrogen receptors (ERs), which regulate the expression of specific target genes after binding to regulatory regions. In addition to its crucial roles in physiology, ER $\alpha$ is also associated with human pathological processes, such as in estrogen-dependent breast cancers (Deroo and Korach, 2006). Approximately $70 \%$ of diagnosed breast cancers express ER $\alpha$, which mediates mitogenic effects in a E2-dependent manner (Dahlman-Wright et al., 2006; Zhao et al., 2008; 2011), and breast tumors expressing ER $\alpha$ often appear to be more differentiated and less invasive than ER $\alpha$-negative cancers (Rochefort et al., 1998; Platet et al., 2004). Furthermore, the proliferation of ER $\alpha$-positive cancer cells can be repressed by anti-estrogens, such as tamoxifen, which are already used in hormone therapy (Wickerham et al., 2009; Kim et al., 2011). For these reasons, ER $\alpha$ expression is generally associated with a good prognosis. Unfortunately, over time, ER $\alpha$-positive breast tumors can escape from hormonal control, becoming resistant to hormone therapy, and switch from a well-differentiated epithelial phenotype to a metastatic and aggressive one (Rau et al., 2005). Hormone-resistant cells frequently exhibit a loss in ER $\alpha$ activity or expression, while the activity of growth receptor signaling increases (Barone et al., 2010; Murphy et al., 2011). For example, the up-regulation of EGFR expression occurs in some tumors and serves as an alternative survival and proliferation pathway (Newby et al., 1997). Despite numerous studies on the topic, the molecular mechanisms involved in the loss of hormonal responses are still unclear.

Growing evidence suggests a role for the myocardin-related transcription factor MKL1 (megakaryoblastic leukemia 1, also termed MRTF-A, MAL, or BSAC) in cancer progression as a tumor-promoting or tumor-suppressor factor, depending on the cellular context (Medjkane et al., 2009; Scharenberg et al., 2010; Hu et al., 2011; Muehlich et al., 2011). MKL1 was first described as a coactivator of serum response factor (SRF) in the control of motile or contractile cell functions, especially during vascular smooth muscle cell and cardiac myocyte differentiation, neuronal 
1 shuttles between the nucleus and cytoplasm via a process controlled by the cellular pool of globular actin

2 (G-actin) (Posern et al., 2002). The nuclear import of MKL1 is regulated by RhoA activity on actin

3 dynamics. Sequestered in an inactive form by G-actin in the cytosol, MKL1 is released following the

4 polymerization of G-actin into filamentous actin (F-actin), which is induced by RhoA (Busche et al.,

5 2008, 2010). Nuclear G-actin has also been demonstrated to facilitate the nuclear export of MKL1.

6 Although the localization and activity of MKL1 are controlled by G-actin, the two events remain

7 independent from each other (Vartiainen et al., 2007; Muehlich et al., 2008). In epithelial-like cells,

8 the actin/MKL1 signaling pathway is notably activated by the loss of cell-cell junctions that occurs

9 during the epithelial-mesenchymal transition (EMT) (Micalizzi et al., 2010).

We have previously shown that the Rho/actin/MKL1 signaling pathway is also a main actor in controlling ER $\alpha$ transcriptional activity (Huet et al., 2008, 2009). In transient transfection experiments, the transactivation efficiency of ER $\alpha$ results in part from the respective contribution exerted by its two activation functions, $\mathrm{AF} 1$ and $\mathrm{AF} 2$, the activities of which are tightly regulated in a cell differentiation stage-dependent manner (Mérot et al., 2004a). Precisely, the more differentiated a cell is, the more that cell mediates ER $\alpha$ signaling through its AF1. In contrast, AF2 is the only active AF in cells that have achieved their EMT (Mérot et al., 2004a). Interestingly, tumor cell lines endogenously expressing ER $\alpha$ exhibit an AF1-permissive cell context, whereas strictly AF-2-permissive tumor cells are always ER $\alpha$ negative. Furthermore, the stable expression of a functional ER $\alpha$ in strictly AF2-permissive cells restores an AF1-sensitive cell context. The transactivation efficiency of ER $\alpha$ was demonstrated to be closely dependent upon the functional state of MKL1. The inhibition of MKL1 activity favors AF1 transactivation of ER $\alpha$; in contrast, the activation of MKL1 silences AF1 activity, thus dramatically reducing the transactivation efficiency of $\mathrm{ER} \alpha$, which then acts exclusively through AF2. Chromatin immunoprecipitation (ChIP) experiments on the ER $\alpha$-positive breast cancer MCF7 cell line showed that MKL1 is present on the promoter of all tested E2-regulated genes (Huet et al., 2009). This presence appears to be mainly E2-independent, and sequential ChIPs indicated a corecruitment with ER $\alpha$ onto several promoters. 
1 is involved in the higher proliferation of ER $\alpha$-negative cell lines that have undergone EMT, in contrast

2 to differentiated ER $\alpha$-positive MCF-7 and T47D cell lines. We further demonstrate that MKL1

3 activation in MCF-7, either by promoting the F/G actin ratio or using MKL1 mutants, induces the

4 hormonal escape of cell growth. This loss of E2 responsiveness is concomitant with the downregulation of $\mathrm{ER} \alpha$ and progesterone receptor (PR) and the enhancement of growth factor signaling.

\section{Materials and methods}

\subsection{Plasmids and transient transfections}

The reporter gene C3 (complement 3)-Luc, the pCR-ER-66, pCR-ER $\alpha-\Delta 79$, and pCR-ER $\alpha-46$ expression vectors, and the CMV- $\beta$ gal internal control vector have been described previously (Mérot et al., 2004b). The V159N and R62D $\beta$-actin mutant expression vectors were kindly provided by Pr. MK. Vartiainen (University of Helsinki, Finland). A 100-ng sample of these expression vectors or control vector (pCR3.1) was used in transient transfection using JetPEI ${ }^{\circledR}$ (Polyplus transfection) according to the manufacturer's protocol. p3Xflag-MKL1, p3Xflag-MKL1 $\Delta$ N200, and p3XflagMKL1 $\Delta \mathrm{C} 301$ expression vectors, which were used to generate the pcDNA4/TO expression vectors, were a gift from Pr. R. Prywes (Colombia University, USA).

\subsection{Antibodies, siRNAs, and reagents}

E2 and 4-hydroxy-tamoxifen (4-OHT) were purchased from Sigma-Aldrich and Alexa Fluor ${ }^{\circledR}$ 594 Phalloidin and DNaseI Alexa Fluor ${ }^{\circledR} 488$ Conjugate from Invitrogen.

Nonspecific siRNA as a control (12935-300, Invitrogen) and an siRNA directed against MKL1 (One-target plus smart pool L-015434-00-0005; Thermo Scientific Dharmacon) were transfected using Lipofectamine ${ }^{\mathrm{TM}} 2000$ (Invitrogen) in accordance with manufacturer's recommendations.

The primary antibodies used for western blotting and immunofluorescence analyses were as follows: rabbit polyclonal (Rp) antibodies against c-Fos (sc-52), ER $\alpha$ (HC-20, sc-543), p-Akt1/2/3 
1 (Ser473)-R (sc-7985-R), Akt1/2/3 (H-136, sc-8312), ERK1 (K-23, sc-94), and SRF (G-20, sc-335), a

2 goat polyclonal antibody directed against MKL1 (MRTF-A C-19, sc-21558), and a mouse monoclonal $3(\mathrm{Mm})$ antibody against p-ERK (sc-7383) or against $\beta$-actin (AC-15, sc-69879) were acquired from

4 Santa Cruz; an Mm anti-flag (clone M2) and Mm anti-vimentin (clone V9) antibody were obtained from Sigma-Aldrich; an Mm anti-PCNA antibody was obtained from Dako; Rp anti-E-cadherin (ab15148), Rp anti-MKL1 (ab113264), and Rp anti-alpha smooth muscle actin (ab5694) antibodies

\subsection{Cell culture and treatments}

MCF-7, T47D, and MDA-MB-231 cells were routinely maintained in DMEM (GIBCO) supplemented with $10 \%$ fetal bovine serum (FBS; Biowest) and antibiotics (GIBCO) at $37^{\circ} \mathrm{C}$ in $5 \%$ $\mathrm{CO}_{2}$. HMT-3522 T4-2 cells (Briand et al., 1996) were routinely maintained in DMEM / hams F12 (GIBCO) supplemented with insulin, transferrin, and sodium selenite (Insulin-Transferrin-Selenium 100X, GIBCO), $10^{-10} \mathrm{M}$ E2, $0.5 \mu \mathrm{g} / \mathrm{mL}$ hydrocortisone (Sigma), and $5 \mu \mathrm{g} / \mathrm{mL}$ ovine prolactin (Sigma). Flasks coated with collagen IV (BD Bioscience) were used for culturing the HMT-3522 T4-2 cells. MCF-7 clones stably transfected with the control or overexpressing the wild-type form of MKL1 (WT) or deleted forms of MKL1 ( $\triangle \mathrm{N} 200$ or $\Delta \mathrm{C} 301)$ tagged with a flag epitope were obtained by transfecting cells with the pcDNA6/TR plasmid and the corresponding pcDNA4/TO expression vectors (T-Rex system, Invitrogen) using JetPEI ${ }^{\circledR}$. The clones were selected in a medium containing 5 $\mu \mathrm{g} / \mathrm{mL}$ blasticidin and $100 \mu \mathrm{g} / \mathrm{mL}$ zeocin (Invitrogen). Individual clones were isolated and grown in a medium containing selective antibiotics to maintain selection pressure. When treatments with steroids were required, the cells were maintained $48 \mathrm{~h}$ in DMEM (GIBCO) supplemented with $2.5 \%$ dextran / charcoal-stripped FBS (dsFBS; Biowest) prior to the experiments. The induction of WT and mutant 
1 MKL1 expression in MCF-7 clones was performed under the same condition with $1 \mu \mathrm{g} / \mathrm{mL}$ 2 tetracycline.

\subsection{Immunofluorescence}

Cells were plated on cover slides. After treatment, phosphate-buffered saline (PBS) containing $4 \%$ paraformaldehyde was used to fix the cells for $10 \mathrm{~min}$. The cells were permeabilized in PBS containing $0.3 \%$ Triton X-100 for $10 \mathrm{~min}$, incubated in sodium citrate for $1 \mathrm{~h}$, and then washed again. The cells were incubated overnight at $4^{\circ} \mathrm{C}$ with primary antibodies; the next day, incubation with secondary antibodies was performed for $2 \mathrm{~h}$ at room temperature. Finally, the cover slides were

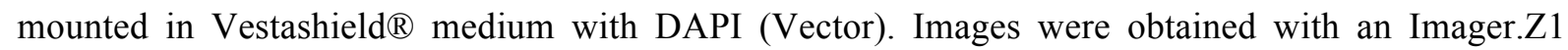
ApoTome AxioCam (Zeiss) microscope.

\subsection{Protein extraction and western blotting}

Whole-cell extracts were directly prepared in 3X Laemmli buffer. Following sonication, the protein extracts were denatured for $5 \mathrm{~min}$ at $95^{\circ} \mathrm{C}$, separated on $10 \%$ SDS polyacrylamide gels, and transferred to polyvinylidene difluoride membrane (Millipore). The proteins were then probed with specific antibodies. An enhanced chemiluminescence system (Immune-Star, Bio-Rad) was used to the detect immunocomplexes.

\subsection{RT-PCR assays}

Trizol $^{\mathrm{TM}}$ reagent (Invitrogen) was used for total RNA extraction according to the manufacturer's protocol. Retrotranscription was performed using MMLV reverse transcriptase. Quantitative RT-PCRs were performed using the $\mathrm{iQ}^{\mathrm{TM}}$ SYBR ${ }^{\circledR}$ Green supermix from BioRad (BioRad, Hercules, CA, USA). 
Cells were maintained for $48 \mathrm{~h}$ in DMEM without phenol red and supplemented with $2.5 \%$ dsFBS for E2 treatments or in DMEM supplemented with $5 \%$ FBS for 4-OHT treatments. After treatment, the cells were trypsinized, fixed for 30 min on ice with $70 \%$ ethanol, and then incubated for $20 \mathrm{~min}$ at $4{ }^{\circ} \mathrm{C}$ in IFA buffer (10 mM HEPES, pH 7.4, $\left.150 \mathrm{mM} \mathrm{NaCl}, 4 \% \mathrm{SVF}\right)$. A 30-min incubation with RNase $\mathrm{A}(100 \mu \mathrm{g} / \mathrm{mL})$ at $37^{\circ} \mathrm{C}$ was then performed, and $25 \mu \mathrm{g} / \mathrm{mL}$ propidium iodide was finally added prior to FACS analysis. A total of $10^{4}$ cells from each sample were analyzed using the FACScan apparatus (Becton-Dickinson).

\subsection{Statistical analysis}

Statistical analyses were performed using Student's t-test. The values are provided as the mean \pm standard error of the mean (SEM).

\section{Results}

\subsection{Hormone-dependent and-independent breast cancer cells exhibit different MKL1 activities}

Four breast cancer cell lines, MCF-7, T47D, HMT-3522 T4-2, and MDA-MB-231, were selected for their differential status with respect to ER $\alpha$, proliferation, and EMT (Fig. 1, panels A and B). MCF-7 and T47D cells express ER $\alpha$ and their proliferation is controlled by estrogen. In contrast, HMT-3522 T4-2 and MDA-MB-231 cells do not express ER $\alpha$ and their proliferation is hormoneindependent. Furthermore, MCF-7 and T47D cells are well-differentiated epithelial cells with a minimally aggressive behavior, whereas HMT-3522 T4-2 and MDA-MB-231 cells are invasive and poorly differentiated. HMT-3522 T4-2 and MDA-MB-231 cell lines have undergone EMT, as shown by the loss of the epithelial adhesion protein E-cadherin and the expression of vimentin, an intermediate filament (Fig. 1, panel A). Changes in actin dynamics are a hallmark of EMT. Therefore, the F/G-actin ratio was determined in the four cell lines by immunofluorescence staining using phalloidin and DNase I, which bind specifically to F- and G-actin, respectively (Fig. 1, panel C). A quantitative assessment of the fluorescence intensity revealed a 2 -fold increase in the F/G-actin ratio in the 
dedifferentiated ER $\alpha$-negative cell lines versus the ER $\alpha$-positive cell lines. Because an increased F/Gactin ratio activates MKL1 (Posern et al., 2002; Busche et al., 2008), the ER $\alpha$-negative cell lines were expected to have higher MKL1 activity. MKL1 was expressed in the four cell lines, as shown by western blotting (Fig. 1, panel B). MKL1 activation is often associated with the massive nuclear accumulation of the protein, though these events are independent from each other (Vartiainen et al., 2007). Immunofluorescence experiments showed differences in the sub-cellular localization of MKL1 between the ER $\alpha$-positive and -negative cells, with a high percentage of cells with nuclear MKL1 in the ER $\alpha$-negative cell lines (Fig. 1, panels A, D). MKL1 is a coactivator of serum response factor (SRF), but the $S R F$ gene is also an important target of the Rho/actin/MKL1 signaling pathways through the SRE in its promoter, providing positive feedback loop regulation. SRF expression was therefore determined by western blotting in the four cell lines. The highest level of SRF expression was detected in the HMT-3522 T4-2 and MDA-MB-231 cells, in agreement with the nuclear localization of MKL1 (Fig. 1, panel B). Finally, corroborating the higher MKL1 activity in the ER $\alpha$ negative cell lines, the respective contribution exerted by the AF1 and AF2 transactivation functions to ER $\alpha$ transcriptional activity was clearly different in the ER $\alpha$-positive and ER $\alpha$-negative cell lines, indicative of a different functional state of MKL1 in these cells (Fig. 1, panel E). Indeed, the failure of $\mathrm{ER} \alpha$ to transactivate E2-regulated reporter genes through the AF1 transactivation function was previously demonstrated to be a consequence of MKL1 activation (Huet et al., 2009). In these experiments, cell permissiveness to either ER $\alpha$ AFs was determined by comparing the transcriptional activity of ER $\alpha$ with that of ER $\alpha \Delta 79$ (deletion of AF1 box 1) and ER $\alpha$ CF (total deletion of AF1).

To identify the involvement of MKL1 in the proliferation of ER $\alpha$-positive and ER $\alpha$-negative cell lines, the impact of MKL1 siRNA knockdown on the percentage of cells in S phase was determined through nuclear PCNA staining in immunofluorescence experiments. As shown in Fig. 1 (panel F), the MCF-7 and T47D cells exhibited a lower percentage of cells in S phase than the HMT-3522 T4-2 and MDAMB-231 cells, as expected. MKL1 silencing by siRNA had no impact on MCF-7 and T47D proliferation, corroborating the fact that MKL1 is not or only weakly active in these cell lines but relevantly reduces the percentage of HMT-3522 T4-2 and MDA-MB-231 cells in S phase. 
1 ER $\alpha$-negative cell lines is in part due to the activation of the actin/MKL1 signaling pathway.

2 Furthermore, these data suggest that hormone-dependent and -independent breast cancer cells might differ with regard to their MKL1 activity.

As previously indicated, differentiated hormone-dependent breast cancer cells exhibit no or low MKL1 activity. EMT is characterized by an increase in the F/G-actin ratio and consequently MKL1 activation (Morita et al., 2007). Hormonal escape is also a hallmark of the progression of hormone-dependent breast cancer cells toward EMT. To verify whether a direct link exits between these two events, we attempted to activate endogenous MKL1 in the hormone-dependent breast cancer MCF-7 cell line by expressing mutant forms of actin that are known to modify the F/G-actin ratio. R62D is a non-polymerizable actin mutant that represses MKL1 activity on SRF target genes. In contrast, Actin-V159N favors F-actin formation and consequently leads to MKL1 activation (Posern et al., 2002). Fig. 2 (panel A) shows the expected changes in the F/G-actin ratio induced by these actin mutants. Interestingly, most of the cells were affected, suggesting that low amounts of transfected plasmids are sufficient to induce these changes and that actin dynamics could be, as with other polymerization phenomena, very sensitive to disrupting molecules. Indicative of cell fate, ER $\alpha$ localization was first assayed by immunofluorescence (Fig. 2, panels B, C). Although the R62D mutant had no or little effect, Actin-V159N induced a clear decrease in ER nuclear localization, slightly leaking to the cytoplasm, which was comparable to the ER $\alpha$ profile observed during E2-induced cell proliferation.

21 Changes in the MKL1 distribution after transfection of the different actin constructs were observed. Indeed, the V159N mutant increased the nuclear translocation of MKL1 (Fig. 2, panel D). The impact of the actin mutants on the percentage of MCF-7 cells in S phase was then determined following PCNA staining (Fig. 2, panel E, left). The results showed a slight but significant reduction in the number of cells in $\mathrm{S}$ phase in the presence of the non-polymerizable R62D actin mutant ( $\mathrm{S}=12.3 \%$ vs $\mathrm{S}=15.7 \%$ in the control, $\mathrm{p}<0.05$ ), whereas the expression of actin-V159N enhanced the number of cells ( $\mathrm{S}=25 \% \mathrm{vs}$

$27 \mathrm{~S}=15.7 \%$ in the control, $\mathrm{p}<0.05$ ). As a consequence, the fold induction of MCF-7 cells in $\mathrm{S}$ phase 
1 observed after E2 treatment was reduced in the cells expressing actin-V159N and increased in the cells

2 expressing actin-R62D (1.7 and 3.6, respectively, for these cells vs 2.7 for the control cells). To evaluate MKL1 involvement in this process, similar experiments were performed in MCF-7 cells in which MKL1 expression was silenced by siRNA. As depicted in Fig. 2 (panel E, right), MKL1 knockdown completely abolished the effect of the R62D $(\mathrm{p}<0.05)$ and V159N $(\mathrm{p}<0.001)$ actin mutants. In contrast, MKL1 repression had no impact on E2-induced proliferation. Similar data were obtained using T47D cells (suppl. 1). Collectively, these results indicate that the activation of the actin/MKL1 pathway induces an enhancement in the percentage of cells in S phase that escape from hormonal control.

\subsection{Expression of a constitutively active form of MKL1 in MCF-7 cells represses ERa} expression and abolishes E2-induced transcription

To further investigate the impact of MKL1 on hormone-dependent breast cancer cells, we generated MCF-7 sub-clones using a tetracycline-inducible vector system to stably express the MKL1WT, $-\Delta \mathrm{N} 200$, or $-\Delta \mathrm{C} 301$ forms. Deleted of the N-terminal RPEL motifs, MKL1- $\Delta \mathrm{N} 200$, is a constitutively active form, whereas MKL1- $\triangle \mathrm{C} 301$ behaves as a dominant negative form due to the deletion of the transactivation domain (Cen et al., 2003). In addition to the first series of individual MCF-7 sub-clones, two individual clones expressing mutant forms of MKL1 were selected (Clones 2 and 3). It should be noted that all the data obtained with these additional clones mostly confirm the results obtained with the first series (clone 1) (suppl. 2). We first controlled MKL1 protein expression in the different sub-clones using western blotting and immunofluorescence methods (Fig. 3, panel A, B, and suppl. 2). Proteins of interest were produced after tetracycline treatment only (suppl. 2). The nuclear localization of Flagged-MKL1-WT and MKL1- $\Delta$ C301 was observed in less than $10 \%$ of the cells, whereas most of the cells showed MKL1- $\Delta$ N200 localized in the nucleus (Fig. 3, panel B). The activity of the MKL1 mutants was confirmed by western blot monitoring of the expression level of SRF, c-fos, or $\alpha$-actin, three known targets of the actin/MKL1 signaling pathway (Fig. 3, panel A, and suppl. 2). Intriguingly, a high expression level of MKL1- $\Delta$ N200 was shown to repress ER $\alpha$ 
1 expression. Corroborating the western blotting analysis, ER $\alpha$ immunostaining performed on the entire

2 cell population revealed a global decrease in ER $\alpha$ expression in the cells expressing the constitutively

3 active form of MKL1 (Fig. 3, panel C). Regardless of the form of MKL1 (WT, MKL1- $\Delta$ N200, and

4 MKL1- $\Delta$ C301), ER was down-regulated when MKL1 was nuclear. Therefore, the nuclear localization of MKL1 proteins and ER $\alpha$ are mutually exclusive (Fig. 3, panel B). Quantitative real-time PCR experiments demonstrated that ER $\alpha$ expression was also repressed at the mRNA level in MCF7/MKL1- $\Delta$ N200 cells (Fig. 3, panel D). Interestingly, MKL1- $\Delta$ N200 also exhibited down-regulated GATA3, a hallmark of hormonal responsiveness. Therefore, the estrogenic responses of PR and pS2, two main E2 target genes, were deeply impacted by MKL1 activities, as expected. Although the expression of both genes was induced by E2 in the MCF-7/cont, MCF-7/MKL1-WT, and MCF7/MKL1- $\triangle$ C301 cells, this regulation was almost completely abolished in the MCF-7/MKL1- $\Delta$ N200 cells.

3.4. Expression of a constitutively active form of MKL1 in MCF-7 cells enhances growth factor signaling and induces hormonal escape

Our study was extended by implementing quantitative real-time PCR experiments targeting the expression of genes encoding members of the growth factor signaling pathway (Fig. 4, panel A, and suppl. 2). TGF $\alpha$ and amphiregulin, two main growth factors in MCF-7 cells, have been previously shown to be up-regulated by E2, whereas the expression of the receptors HER1 and HER2 is repressed (Normanno et al., 1993; Zhang et al., 1994; Dardes et al., 2002). As expected, the expression of TGF $\alpha$ and amphiregulin was induced by E2 in the MCF-7/cont, MCF-7/MKL1, and MCF-7/MKL1- $\Delta$ C301 cells. HER1 and HER2 expression was also repressed by E2 in these three cell lines. Surprisingly, the expression of the TGF $\alpha$ and amphiregulin genes was strongly enhanced in a hormone-independent manner in MCF-7/MKL1- $\Delta$ N200. In the same way, HB-EGF, a membrane-bound growth factor overexpressed in malignant cells (Miyamoto et al., 2006), was dramatically up-regulated in these cells. In parallel, the expression level of the receptor HER1 was no longer down-regulated by E2, remaining at a high level in the presence of the steroid. Finally, HER2 expression was clearly down-regulated in a 
1 hormone-independent manner in the MCF-7/MKL1- $\Delta$ N200 cells. Western blots probing the

2 MAPK/ERK and PI3K/Akt signaling pathways revealed an activation of these signaling pathways in 3 the MCF-7/MKL1- $\triangle$ N200 compared to control or MCF-7/MKL1 cells (Fig. 4, panel B, and suppl. 2).

4 Finally, regarded as one of the main axes involved in the control of proliferation/metastasis balance, 5 the chemokine CXCL12 and its receptor CXCR4 are both E2-regulated genes (Habauzit et al., 2010;

6 Boudot et al., 2011). The constitutively active form of MKL1 completely abolished the E2-dependent 7 regulation of this axis and induced an interesting profile characterized by low CXCL12 and a high level of CXCR4.

A flow cytometry analysis was carried out on the different MCF-7 sub-clones to study the relative proportion of cells in the different cell cycle phases (Fig. 4, panel C). Compared to the control cells, WT MKL1 over-expression did not affect the percentage of cells in S phase, though the expression of the dominant negative form $(\Delta \mathrm{C} 301)$ slightly reduced it. As expected, E2 treatment enhanced the percentage of cells in S phase in these three MCF-7 sub-clones. The highest fold E2induction was generally detected in the cells expressing MKL1- $\Delta$ C301. In parallel, the E2 induction of cells in S phase was almost completely abolished in the MCF-7/MKL1- $\triangle \mathrm{N} 200$ cells. The percentages of cells in S phase were generally slightly enhanced in these cells, albeit with some variations between clones. These variations might be related to changes in the balance of proliferation/migration between MCF-7/MKL1- $\Delta$ N200 clones. The highest E2-independent increase in cells in S phase was observed in clone 1 (Fig. 4, panel C) and was accompanied by an enhancement in cells in SubG1, a sign of apoptosis or necrosis. The presence of blebbing cells with the loss of cell membrane integrity and the absence of Poly (ADP-ribose) polymerase (PARP) cleavage was indicative of a necrotic process (data not shown). A cell counting assay showed that changes in the different cell cycle phases impacted cell growth, as expected (Fig. 4, panel D).

Altogether, these results indicate that the activation of MKL1 in MCF-7 cells induces the hormonal escape of cell growth concomitant with an in increase in activity of the growth factor signaling pathway. 
Because the deregulation of E2-induced proliferation is often associated with resistance to

2 tamoxifen, we then assessed the impact of tamoxifen treatment on cell growth. For that purpose, the

3 four MCF-7 sub-clones were cultivated in media containing 5\% FBS and treated for $48 \mathrm{~h}$ with 4-OHT

4 or vehicle; the cell cycle was then analyzed by flow cytometry (Fig. 5, panel A). In the MCF-7/cont,

5 MCF-7/MKL1, and MCF-7/MKL1- $\Delta$ C301 clones, the percentage of cells in S phase was significantly

6 reduced by the 4-OHT treatment. The strongest effect was observed in the MCF-7/MKL1- $\Delta$ C301

7 cells, with an almost 3-fold reduction of cells in S phase. In contrast, the percentage of MCF-7/MKL1-

$8 \Delta \mathrm{N} 200$ cells in $\mathrm{S}$ phase was unaffected by the $4-\mathrm{OHT}$ treatment $(\mathrm{S}=21 \%$ vs $\mathrm{S}=23 \%)$. This resistance

9 of MCF-7/MKL1- $\Delta$ N200 cells to tamoxifen was also confirmed in qPCR assays, with the most

obvious effect observed for the growth factors TGF $\alpha$ and amphiregulin (Fig. 4, panel B). High

expression was measured even in the presence of 4-OHT. Constitutively repressed in MCF-7/MKL1-

$\Delta$ N200 cells, ER, PR, and CXCL12 gene expression was not further affected by the 4-OHT treatment.

Taken together, these results indicate that MKL1 activation promotes resistance to tamoxifen in breast cancer cells.

\section{Discussion}

Identifying the mechanisms underlying endocrine resistance is the topic of intensive investigation.

In the case of hormone-dependent breast cancers, endocrine therapies target ER $\alpha$ function either directly through the use of an antagonist specific ligand such as tamoxifen or fulvestrant or indirectly by depriving cancer cells from estrogen using aromatase inhibitors. Thus, the loss of ER $\alpha$ activity or expression and the onset of the hormonal escape of breast cancer proliferation has tragic consequences on prognoses and treatments.

In the present study, we investigated the impact of MKL1, a transcriptional integrator of actin dynamics originally identified in acute megakaryoblastic leukemia, on breast cancer cells with regard to ER $\alpha$ status and estrogenic responsiveness. Growing evidence suggests both positive and negative roles for MKL1 in tumorigenesis and cancer progression (Milyavsky et al., 2007; Medjkane et al.,

27 2009; Scharenberg et al., 2010). First, it is known that changes in cell contacts and in cytoskeletal 
1 conformation, which occur during EMT, result in the activation of MKL1 (Morita et al., 2007).

2 Second, the expression of SCAI (Suppressor of CAncer cell Invasion), a cofactor inhibiting MKL1

3 activity, has been shown to be inversely correlated with cancer aggressiveness and is down-regulated

4 in many human tumors, including breast tumors (Brandt et al., 2009). Finally, the activation of MKL1 was recently shown to be a pro-tumorigenic event in human hepatocarcinogenesis (Muehlich et al., 2011). Our results showed that MKL1 also mediates the loss of estrogenic responsiveness in breast cancer cells, allowing them to become hormone resistant. The comparison of ER $\alpha$-positive MCF-7 and T47D breast cancer cells with ER $\alpha$-negative HMT-3522 T4-2 and MDA-MB-231 cells demonstrated that MKL1 activity is higher in hormone-independent breast cancer cell lines. In these latter cells, MKL1 activity was at least in part responsible for their higher proliferation rate, as shown by siRNA knockdown experiments. Furthermore, expression of the constitutively active form of MKL1 in MCF7 cells abrogated E2 regulation and slightly increased the percentage of cells in S phase in an E2independent manner. In contrast, expression of the dominant negative form of MKL1 favored cell quiescence in E2-free medium, allowing an efficient control of the mitogenic effect of E2. In parallel, ER $\alpha$ expression was almost completely repressed by the constitutively active form of MKL1. Similar results were obtained by artificially changing the F/G-actin ratio with actin mutants, though in a less efficient manner. Several mechanisms have been described to explain ER $\alpha$ silencing in breast cancer cells (Musgrove and Sutherland, 2009), and MKL1 activation during tumor progression could be another explanation. Expression of the constitutively active form of MKL1 in MCF-7 cells induced resistance to tamoxifen, a selective ER modulator that abolishes tumor growth (Jordan, 2003), suggesting that MKL1 activation during cancer progression could be a potential mechanism by which breast cancer cells escape from hormonal control and become resistant to hormonal therapies.

With regard to our observations in breast cancer cell lines, it is conceivable that mutations leading to constitutive or over-active MKL1 of could induce hormonal escape and the loss of ER $\alpha$ expression in breast tumors. To our knowledge, no studies have described activating mutations of MKL1 in tumors. Nevertheless, an MKL1 promoter single-nucleotide polymorphism (SNP) resulting in MKL1 overexpression has been linked to atherosclerosis progression and coronary artery disease (Hinohara et al., 2009). More recently, SNPs in the MKL1 locus were also shown to be associated 
1 with triple-negative breast cancer (Purrington et al., 2013). The impact of these polymorphisms in 2 breast tumor progression could be suspected. Obviously, more investigations should be conducted to study MKL1 activation and potential MKL1 mutations in tumor cells and to correlate them with ERand endocrine resistance-tumor status. However, it is likely that the activation of MKL1 in tumor cells results more from modifications of the microenvironment occurring during cancer progression rather than direct MKL1 mutation.

To mechanistically investigate MKL1 action, we analyzed the expression profile of several E2-regulated and growth factor genes following MKL1 activation. First, confirming the repressive effect of MKL1 on ER $\alpha$ expression, all of the tested genes lost their estrogenic regulation in the presence of the constitutively active form of MKL1. This finding is substantiated by the repression of GATA3, a pioneer factor essential for an E2 response and considered to be a marker of hormonal response (Eeckhoute et al., 2007). Additionally, MKL1 activation enhanced TGF $\alpha$, amphiregulin, and HB-EGF expression. The over-expression of different components of growth factor pathways is generally a hallmark of hormone-resistant breast cancer cells and is thought to explain the increased proliferation rate of these cells (Massarweh and Schiff, 2006). Corroborating this observation, an increase in ERK phosphorylation was detected in cells expressing the MKL1- $\Delta$ N200 form. Regulated in part by growth factors, MAPK/ERK is a downstream signaling pathway mediating several cellular responses, such as proliferation. Concordant with a growth escape from estrogenic control is the repression of the chemokine CXCL12. This factor has been clearly demonstrated to be one of the key mediators in the estrogen-dependent growth of breast cancer cells (Hall, 2003; Boudot et al., 2011). Furthermore, CXCL12 repression is correlated with poor disease-free and overall survival in both ER $\alpha$-positive and ER $\alpha$-negative breast cancers (Mirisola et al., 2009). Finally, it has been demonstrated that the overexpression of the CXCL12 receptor, CXCR4, allows cancer cells to maintain their growth ability when treated with anti-estrogens (Rhodes et al., 2010). Further insights are now necessary to understand the mechanisms engaged by MKL1 to influence estrogen signaling in breast cancer cells. MKL1 activation is often associated with the nuclear accumulation of the protein, and indeed, we observed that the nuclear translocation of MKL1 was higher in the ER $\alpha$-negative EMT-like cell lines than the ER $\alpha$-positive cell lines. However, it should be 
mentioned that changes in the sub-cellular localization of MKL1 are not always detected, despite differences in the transcriptional activity and expression of ER $\alpha$ (Huet et al., 2009). The cell support, serum, or antibody used could result in changes in nuclear MKL1 just below the detection limit. We have previously shown in ChIP experiments that MKL1 is recruited to the promoters of E2-responsive genes in MCF-7 cells, though no massive nuclear translocation of MKL1 is observed (Huet et al., 2009). Although MKL1 was co-recruited with ER $\alpha$ to the promoter regions of some E2-regulated genes, we failed to detect a clear direct interaction between both proteins in in vitro GST-pull-down experiments (data not shown). Furthermore, the association of MKL1 with E2-regulated promoters appeared to be constitutive because it is also observed in the absence of estradiol and ERs. Similarly, the E2-independent induction of some growth factors, such as TGF $\alpha$ and amphiregulin, measured in the presence of the constitutively active form of MKL1 occurred with low or no ER $\alpha$ expression. Finally, we previously reported changes in the transcriptional activity of ERE- and SRE-less reporter genes following the overexpression of WT and mutant forms of MKL1 (Huet et al., 2009). Therefore, it seems obvious that MKL1 acts through a mechanism that is independent of its interaction with ER $\alpha$. The hormonal escape of estrogen-responsive breast cancer cells might instead be the result of a more global role of MKL1 on the differentiation/de-differentiation balance through a yet-unknown mechanism that allows global genetic reprogramming. Notably, the existence of several similarities between the effects of the constitutively active form of MKL1 and the effects of HDAC inhibitors on estrogen signaling in breast cancer cells (data not shown) should prompt us to study more extensively the epigenetic regulations by MKL1.

MKL1 has also recently been implicated in tumor cell invasion and metastasis (Medjkane et al., 2009). Despite their mitogenic role, TGF $\alpha$, amphiregulin, and HB-EGF have also been associated with enhanced cell motility and invasion (Willmarth and Ethier, 2006; Bos et al., 2009; Kikuchi et al., 2011). The increased expression of these growth factors when MKL1 is activated may corroborate a pro-metastasis effect of MKL1. The CXCL12 axis is also involved in migration and metastasis, especially in breast cancer. Indeed, metastatic breast cancer cells generally express high levels of CXCR4 and preferentially migrate to and colonize organs that express high levels of CXCL12, such as the brain, bone, liver, and lung (Luker and Luker, 2006; Kerdivel et al., 2013). Interestingly, MKL1 did repress the ligand CXCL12 and induced the expression of its receptor (CXCR4), likely promoting 
1 the migration of cancer cells. Variations in the proliferation/migration balance might explain the

2 observed differences in cell growth between MCF-7 clones expressing the constitutively active form

3 of MKL1.

Finally, the expression profile in cells expressing the constitutively active form of MKL1 led to an intriguing observation. Indeed, the activation of MKL1 repressed the expression of ER, PR, and HER2, a typical profile of triple-negative breast cancer tumors (TNBCs). Interestingly, the MKL1 locus was recently identified as a susceptible risk factor for TNBCs (Purrington et al., 2013). TNBCs represent approximately $15 \%$ of breast cancers and are a poor prognostic factor for survival. Indeed TNBCs generally exhibit a more aggressive phenotype, and there is a lack of available effective targeted therapies (Rastelli et al., 2010). In association with classical chemotherapies, targeting MKL1 in this cancer subtype could be promising to reduce their aggressiveness. Stably expressing the inactive form MKL1- $\triangle \mathrm{C} 301$ in ER $\alpha$-negative MDA-MB 231 cells was not sufficient to restore hormonal control (suppl. 3). A drug inhibiting MKL1-dependent transcription, CCG-1423 (Evelyn et al., 2007), is already available, but more investigations should be performed to reveal a potential relevance to breast cancer treatment.

In conclusion, our study highlights the impact of MKL1 activation on MCF-7 breast cancer cell proliferation and its role in the acquisition of a hormone-independent phenotype. With regard to its hormonal escape-promoting effect, the MKL1 pathway could represent an interesting target for mammary tumor therapies.

\section{Conflict of interest}

The authors declare no conflict of interest.

\section{Acknowledgments}

We thank Pr. Vartiainen and Pr. Prywes for providing plasmids. This work was supported by fellowships from The Région Bretagne, the CNRS, the Ligue Contre le Cancer, the University of Rennes 1, and the European University of Brittany. 


\section{References}

3 Barone, I., Brusco, L., Fuqua, S.A.W., 2010. Estrogen receptor mutations and changes in

4 downstream gene expression and signaling. Clin. Cancer Res. 16, 2702-2708.

5 Bos, P.D., Zhang, X.H.-F., Nadal, C., Shu, W., Gomis, R.R., Nguyen, D.X., Minn, A.J., van

6 de Vijver, M.J., Gerald, W.L., Foekens, J.A., Massagué, J., 2009. Genes that mediate breast

7 cancer metastasis to the brain. Nature 459, 1005-1009.

8 Boudot, A., Kerdivel, G., Habauzit, D., Eeckhoute, J., Le Dily, F., Flouriot, G., Samson, M.,

9 Pakdel, F., 2011. Differential estrogen-regulation of CXCL12 chemokine receptors, CXCR4

10 and CXCR7, contributes to the growth effect of estrogens in breast cancer cells. PLoS ONE 6,

$11 \mathrm{e} 20898$.

12 Brandt, D.T., Xu, J., Steinbeisser, H., Grosse, R., 2009. Regulation of myocardin-related 13 transcriptional coactivators through cofactor interactions in differentiation and cancer. Cell 14 Cycle 8, 2523-2527.

Briand, P., Nielsen, K.V., Madsen, M.W., Petersen, O.W., 1996. Trisomy 7p and malignant transformation of human breast epithelial cells following epidermal growth factor withdrawal. Cancer Res. 56, 2039-2044.

Busche, S., Descot, A., Julien, S., Genth, H., Posern, G., 2008. Epithelial cell-cell contacts regulate SRF-mediated transcription via Rac-actin-MAL signalling. J. Cell. Sci. 121, 10251035.

Busche, S., Kremmer, E., Posern, G., 2010. E-cadherin regulates MAL-SRF-mediated transcription in epithelial cells. J. Cell. Sci. 123, 2803-2809.

Cen, B., Selvaraj, A., Burgess, R.C., Hitzler, J.K., Ma, Z., Morris, S.W., Prywes, R., 2003. Megakaryoblastic leukemia 1, a potent transcriptional coactivator for serum response factor (SRF), is required for serum induction of SRF target genes. Mol. Cell. Biol. 23, 6597-6608. 
1 Couse, J.F., Korach, K.S., 1999. Estrogen receptor null mice: what have we learned and 2 where will they lead us? Endocr. Rev. 20, 358-417.

3 Dahlman-Wright, K., Cavailles, V., Fuqua, S.A., Jordan, V.C., Katzenellenbogen, J.A., 4 Korach, K.S., Maggi, A., Muramatsu, M., Parker, M.G., Gustafsson, J.-A., 2006. International 5 Union of Pharmacology. LXIV. Estrogen receptors. Pharmacol. Rev. 58, 773-781.

6 Dardes, R.C., Schafer, J.M., Pearce, S.T., Osipo, C., Chen, B., Jordan, V.C., 2002. Regulation 7 of estrogen target genes and growth by selective estrogen-receptor modulators in endometrial 8 cancer cells. Gynecol. Oncol. 85, 498-506.

9 Deroo, B.J., Korach, K.S., 2006. Estrogen receptors and human disease. J. Clin. Invest. 116, $10 \quad 561-570$.

11 Eeckhoute, J., Keeton, E.K., Lupien, M., Krum, S.A., Carroll, J.S., Brown, M., 2007. Positive 12 cross-regulatory loop ties GATA-3 to estrogen receptor alpha expression in breast cancer. 13 Cancer Res. 67, 6477-6483.

14 Evelyn, C.R., Wade, S.M., Wang, Q., Wu, M., Iñiguez-Lluhí, J.A., Merajver, S.D., Neubig, R.R., 2007. CCG-1423: a small-molecule inhibitor of RhoA transcriptional signaling. Mol.

16 Cancer Ther. 6, 2249-2260.

17 Habauzit, D., Boudot, A., Kerdivel, G., Flouriot, G., Pakdel, F., 2010. Development and validation of a test for environmental estrogens: Checking xeno-estrogen activity by CXCL12 secretion in BREAST CANCER CELL LINES (CXCL-test). Environ. Toxicol. 25, 495-503. Hall, J.M., 2003. Stromal Cell-Derived Factor 1, a Novel Target of Estrogen Receptor Action,

21 Mediates the Mitogenic Effects of Estradiol in Ovarian and Breast Cancer Cells. Molecular 22 Endocrinology 17, 792-803.

23 Hinohara, K., Nakajima, T., Yasunami, M., Houda, S., Sasaoka, T., Yamamoto, K., Lee, B.24 S., Shibata, H., Tanaka-Takahashi, Y., Takahashi, M., Arimura, T., Sato, A., Naruse, T., Ban, 25 J., Inoko, H., Yamada, Y., Sawabe, M., Park, J.-E., Izumi, T., Kimura, A., 2009. 
1 Megakaryoblastic leukemia factor-1 gene in the susceptibility to coronary artery disease.

2 Hum. Genet. 126, 539-547.

$3 \mathrm{Hu}$, Q., Guo, C., Li, Y., Aronow, B.J., Zhang, J., 2011. LMO7 Mediates Cell-Specific

4 Activation of the Rho-Myocardin-Related Transcription Factor-Serum Response Factor

5 Pathway and Plays an Important Role in Breast Cancer Cell Migration. Molecular and

6 Cellular Biology 31, 3223-3240.

7 Huet, G., Mérot, Y., Le Dily, F., Kern, L., Ferrière, F., Saligaut, C., Boujrad, N., Pakdel, F.,

8 Métivier, R., Flouriot, G., 2008. Loss of E-cadherin-mediated cell contacts reduces estrogen

9 receptor alpha (ER alpha) transcriptional efficiency by affecting the respective contribution

10 exerted by AF1 and AF2 transactivation functions. Biochem. Biophys. Res. Commun. 365,

$11304-309$.

12 Huet, G., Mérot, Y., Percevault, F., Tiffoche, C., Arnal, J.-F., Boujrad, N., Pakdel, F.,

13 Métivier, R., Flouriot, G., 2009. Repression of the estrogen receptor-alpha transcriptional

14 activity by the Rho/megakaryoblastic leukemia 1 signaling pathway. J. Biol. Chem. 284, $15 \quad 33729-33739$.

16 Jordan, V.C., 2003. Antiestrogens and selective estrogen receptor modulators as

17 multifunctional medicines. 2. Clinical considerations and new agents. J. Med. Chem. 46, $18 \quad 1081-1111$

19 Kerdivel, G., Boudot, A., Pakdel, F., 2013. Estrogen represses CXCR7 gene expression by 20 inhibiting the recruitment of $\mathrm{NF \kappa B}$ transcription factor at the CXCR7 promoter in breast 21 cancer cells. Biochem. Biophys. Res. Commun.

22 Kikuchi, K., Li, X., Zheng, Y., Takano, Y., 2011. Invasion of breast cancer cells into collagen 23 matrix requires TGF- $\alpha$ and Cdc42 signaling. FEBS Lett. 585, 286-290.

24 Kim, C., Tang, G., Pogue-Geile, K.L., Costantino, J.P., Baehner, F.L., Baker, J., Cronin, 25 M.T., Watson, D., Shak, S., Bohn, O.L., Fumagalli, D., Taniyama, Y., Lee, A., Reilly, M.L., 
1 Vogel, V.G., McCaskill-Stevens, W., Ford, L.G., Geyer, C.E., Jr, Wickerham, D.L.,

2 Wolmark, N., Paik, S., 2011. Estrogen receptor (ESR1) mRNA expression and benefit from

3 tamoxifen in the treatment and prevention of estrogen receptor-positive breast cancer. J. Clin.

4 Oncol. 29, 4160-4167.

5 Luker, K.E., Luker, G.D., 2006. Functions of CXCL12 and CXCR4 in breast cancer. Cancer 6 letters $238,30-41$.

7 Massarweh, S., Schiff, R., 2006. Resistance to endocrine therapy in breast cancer: exploiting estrogen receptor/growth factor signaling crosstalk. Endocr. Relat. Cancer 13 Suppl 1, S1524.

Medjkane, S., Perez-Sanchez, C., Gaggioli, C., Sahai, E., Treisman, R., 2009. Myocardin-

11 related transcription factors and SRF are required for cytoskeletal dynamics and experimental metastasis. Nat. Cell Biol. 11, 257-268.

Mérot, Y., Métivier, R., Penot, G., Manu, D., Saligaut, C., Gannon, F., Pakdel, F., Kah, O.,

14 Flouriot, G., 2004a. The relative contribution exerted by AF-1 and AF-2 transactivation functions in estrogen receptor alpha transcriptional activity depends upon the differentiation 16 stage of the cell. J. Biol. Chem. 279, 26184-26191.

17 Mérot, Y., Métivier, R., Penot, G., Manu, D., Saligaut, C., Gannon, F., Pakdel, F., Kah, O., 18 Flouriot, G., 2004b. The relative contribution exerted by AF-1 and AF-2 transactivation 19 functions in estrogen receptor alpha transcriptional activity depends upon the differentiation 20 stage of the cell. J. Biol. Chem. 279, 26184-26191.

21 Micalizzi, D.S., Farabaugh, S.M., Ford, H.L., 2010. Epithelial-mesenchymal transition in 22 cancer: parallels between normal development and tumor progression. J Mammary Gland 23 Biol Neoplasia 15, 117-134.

24 Milyavsky, M., Shats, I., Cholostoy, A., Brosh, R., Buganim, Y., Weisz, L., Kogan, I., Cohen, 25 M., Shatz, M., Madar, S., Kalo, E., Goldfinger, N., Yuan, J., Ron, S., MacKenzie, K., Eden, 
1 A., Rotter, V., 2007. Inactivation of myocardin and p16 during malignant transformation

2 contributes to a differentiation defect. Cancer Cell 11, 133-146.

3 Mirisola, V., Zuccarino, A., Bachmeier, B.E., Sormani, M.P., Falter, J., Nerlich, A., Pfeffer,

4 U., 2009. CXCL12/SDF1 expression by breast cancers is an independent prognostic marker

5 of disease-free and overall survival. Eur. J. Cancer 45, 2579-2587.

6 Miyamoto, S., Yagi, H., Yotsumoto, F., Kawarabayashi, T., Mekada, E., 2006. Heparin-

7 binding epidermal growth factor-like growth factor as a novel targeting molecule for cancer

8 therapy. Cancer Sci. 97, 341-347.

9 Morita, T., Mayanagi, T., Sobue, K., 2007. Dual roles of myocardin-related transcription 10 factors in epithelial mesenchymal transition via slug induction and actin remodeling. J. Cell 11 Biol. 179, 1027-1042.

12 Muehlich S, Hampl V, Khalid S, Singer S, Frank N, Breuhahn K, et al. (2011). The 13 transcriptional coactivators megakaryoblastic leukemia $1 / 2$ mediate the effects of loss of the 14 tumor suppressor deleted in liver cancer 1. Oncogene; e-pub ahead of print 5 December 2011; 15 doi: 10.1038/onc.2011.560.

16 Muehlich, S., Wang, R., Lee, S.-M., Lewis, T.C., Dai, C., Prywes, R., 2008. Serum-induced 17 phosphorylation of the serum response factor coactivator MKL1 by the extracellular signal18 regulated kinase 1/2 pathway inhibits its nuclear localization. Mol. Cell. Biol. 28, 6302-6313.

19 Murphy, L.C., Seekallu, S.V., Watson, P.H., 2011. Clinical significance of estrogen receptor 20 phosphorylation. Endocr. Relat. Cancer 18, R1-14.

21 Musgrove, E.A., Sutherland, R.L., 2009. Biological determinants of endocrine resistance in 22 breast cancer. Nat. Rev. Cancer 9, 631-643.

23 Newby, J.C., Johnston, S.R., Smith, I.E., Dowsett, M., 1997. Expression of epidermal growth 24 factor receptor and c-erbB2 during the development of tamoxifen resistance in human breast 25 cancer. Clin. Cancer Res. 3, 1643-1651. 
1 Normanno, N., Qi, C., Gullick, W., Persico, G., Yarden, Y., Wen, D., Plowman, G., Kenney,

2 N., Johnson, G., Kim, N., Brandt, R., Martinezlacaci, I., Dickson, R., Salomon, D., 1993.

3 Expression of amphiregulin, cripto-1, and heregulin-alpha in human breast-cancer cells. Int. J.

4 Oncol. 2, 903-911.

5 Platet, N., Cathiard, A.M., Gleizes, M., Garcia, M., 2004. Estrogens and their receptors in

6 breast cancer progression: a dual role in cancer proliferation and invasion. Crit. Rev. Oncol.

7 Hematol. 51, 55-67.

8 Posern, G., Sotiropoulos, A., Treisman, R., 2002. Mutant actins demonstrate a role for

9 unpolymerized actin in control of transcription by serum response factor. Mol. Biol. Cell 13, $10 \quad 4167-4178$.

11 Purrington, K.S., Slager, S., Eccles, D., Yannoukakos, D., Fasching, P.A., Miron, P., 12 Carpenter, J., et al. 2013. Genome-wide association study identifies 25 known breast cancer 13 susceptibility loci as risk factors for triple-negative breast cancer. Carcinogenesis (Epub ahead 14 of print).

Rastelli, F., Biancanelli, S., Falzetta, A., Martignetti, A., Casi, C., Bascioni, R., Giustini, L., 16 Crispino, S., 2010. Triple-negative breast cancer: current state of the art. Tumori 96, 875-888. 17 Rau, K.-M., Kang, H.-Y., Cha, T.-L., Miller, S.A., Hung, M.-C., 2005. The mechanisms and managements of hormone-therapy resistance in breast and prostate cancers. Endocr. Relat.

Rhodes, L.V., Short, S.P., Neel, N.F., Salvo, V.A., Zhu, Y., Elliott, S., Wei, Y., Yu, D., Sun, 21 M., Muir, S.E., Fonseca, J.P., Bratton, M.R., Segar, C., Tilghman, S.L., Sobolik-Delmaire, T., 22 Horton, L.W., Zaja-Milatovic, S., Collins-Burow, B.M., Wadsworth, S., Beckman, B.S., 23 Wood, C.E., Fuqua, S.A., Nephew, K.P., Dent, P., Worthylake, R.A., Curiel, T.J., Hung, M.- 
1 Independent Tumorigenesis, Metastasis, and Resistance to Endocrine Therapy in Human

2 Breast Cancer. Cancer Research 71, 603-613.

3 Rochefort, H., Platet, N., Hayashido, Y., Derocq, D., Lucas, A., Cunat, S., Garcia, M., 1998.

4 Estrogen receptor mediated inhibition of cancer cell invasion and motility: an overview. J.

5 Steroid Biochem. Mol. Biol. 65, 163-168.

6 Scharenberg, M.A., Chiquet-Ehrismann, R., Asparuhova, M.B., 2010. Megakaryoblastic

7 leukemia protein-1 (MKL1): Increasing evidence for an involvement in cancer progression 8 and metastasis. Int. J. Biochem. Cell Biol. 42, 1911-1914.

9 Vartiainen, M.K., Guettler, S., Larijani, B., Treisman, R., 2007. Nuclear actin regulates 10 dynamic subcellular localization and activity of the SRF cofactor MAL. Science 316, 1749$11 \quad 1752$.

12 Wickerham, D.L., Costantino, J.P., Vogel, V.G., Cronin, W.M., Cecchini, R.S., Ford, L.G., 13 Wolmark, N., 2009. The use of tamoxifen and raloxifene for the prevention of breast cancer. 14 Recent Results Cancer Res. 181, 113-119.

15 Willmarth, N.E., Ethier, S.P., 2006. Autocrine and Juxtacrine Effects of Amphiregulin on the 16 Proliferative, Invasive, and Migratory Properties of Normal and Neoplastic Human Mammary 17 Epithelial Cells. J. Biol. Chem. 281, 37728-37737.

18 Zhang, Z., Funk, C., Roy, D., Glasser, S., Mulholland, J., 1994. Heparin-binding epidermal 19 growth factor-like growth factor is differentially regulated by progesterone and estradiol in rat 20 uterine epithelial and stromal cells. Endocrinology 134, 1089-1094.

21 Zhao, C., Dahlman-Wright, K., Gustafsson, J.-A., 2008. Estrogen receptor beta: an overview 22 and update. Nucl Recept Signal 6, e003. 


\section{Figure Legends:}

2 Fig. 1: ER-negative MDA-MB-231 and HMT-3522 T4-2 cells differ from ER-positive MCF-7 and

3 T47D cells in the activation of the actin/MKL1 signaling pathway. MCF-7, T47D, HMT-3522 T4-2,

4 and MDA-MB-231 (MDA) cells were grown in 2.5\% dextran-treated charcoal-stripped FBS. (panel

5 A) The expression and subcellular localization of E-cadherin, vimentin, ER $\alpha$, and MKL1 were analyzed by immunofluorescence assays in MCF-7, T47D, HMT-3522 T4-2, and MDA-MB-231 breast cancer cells. (panel B) Total protein samples isolated from MCF-7, T47D, HMT-3522 T4-2, and MDA-MB-231 cells were immunoblotted for MKL1, ER $\alpha$, and SRF; ERK was used as a control. (panel C) F-actin and G-actin staining were analyzed by immunofluorescence using Alexa Fluor 594 phalloidin and Alexa Fluor 488 DNase I, respectively. The signal intensities were quantified using Image-J software and are expressed as the percentage of the intensity measured in MCF-7 cells. The relative F/G actin ratio was then determined. (panel D) Localization of MKL1 was analyzed by immunofluorescence assays in MCF-7, T47D, HMT-3522 T4-2, and MDA-MB-231 cells, and the percentage of cells with nuclear MKL1 staining was quantified. (panel E) Cells were transiently transfected with a C3-LUC reporter gene (100 ng), $50 \mathrm{ng}$ of ER $\alpha$, ER $\alpha \Delta 79$, or ER $\alpha$ CF expression vector (gray histograms), or control vector (black histograms) and $50 \mathrm{ng}$ of the internal control CMV$\beta g a l$. The cells were treated for $48 \mathrm{~h}$ with $10^{-8} \mathrm{M}$ E2. Luciferase activities were normalized to $\beta$ galactosidase and are expressed as the fold increase above the levels measured in the absence of ER $\alpha$ for each cell line. A schematic illustration of the sequence of ER $\alpha$ and of the two N-terminal truncated forms, ER $\alpha \Delta 79$ and ER $\alpha \mathrm{CF}$, is shown. (panel F) MCF-7, T47D, HMT-3522 T4-2, and MDA-MB231 cells were transfected with siRNA targeting MKL1 or with a control siRNA 16 hours before treatment. PCNA staining was visualized by immunofluorescence to determine the percentages of cells in S phase. The western blot presented in the right panel verifies the efficiency of the siRNAs. All the data are mean values from at least triplicate experiments $\pm \operatorname{SEM}(* * * \mathrm{P}<0.001)$.

Fig. 2: MCF-7 cell proliferation is regulated by actin dynamics through MKL1. MCF-7 cells were transiently transfected with actin-R62D or -V159N mutant expression vectors or control vector and 
1 treated with vehicle or $10^{-8} \mathrm{M} \mathrm{E2}$. (panel A) The impact of actin-R62D or -V159N expression on the

2 F/G actin ratio was assayed. F-actin and G-actin staining was analyzed by immunofluorescence using

3 Alexa Fluor 594 phalloidin and Alexa Fluor 488 DNase I, respectively. The fluorescence intensities

4 were quantified using Image-J software and are expressed as percentage of the intensity measured in the cells transfected with control vector. The relative $F / G$ actin ratio then determined $(n=14 ; P<0.05)$. (panel B) The expression and subcellular localization of ER $\alpha$ were analyzed by immunofluorescence assays. (panel C) The fluorescence intensity of nuclear ER $\alpha$ was quantified using Image-J software and normalized as a percentage of the control. Significant differences $(\mathrm{P}<0.05)$ are indicated by different lowercase letters. (panel D) Localization of MKL1 was analyzed by immunofluorescence assays in MCF-7 cells transfected with actin mutants or control expression vectors, and the percentage of cells with nuclear MKL1 staining was quantified. (panel E) MCF-7 cells were transfected with an siRNA targeting MKL1 or with a control siRNA and 24 hours later with actin mutant expression vectors. After 16 hours, the cells were treated for $48 \mathrm{~h}$ with $10^{-8} \mathrm{M}$ E2 or vehicle in the presence of 2.5\% dextran-treated charcoal-stripped FBS. PCNA staining was visualized by immunofluorescence, and the percentage of cells in $\mathrm{S}$ phase was determined. The mean values from at least three experiments \pm SEM are shown. Significant differences $(\mathrm{P}<0.05)$ are indicated by different lowercase letters. Asterisks illustrate significant differences $\left({ }^{*} \mathrm{P}<0.05,{ }^{* * *} \mathrm{P}<0.001\right)$ between the cells transfected with control SiRNA or MKL-1-targeted siRNA.

Fig. 3: A constitutively active form of MKL1 impairs the estrogenic response in MCF-7 cells. MCF-7 sub-clones (Clone 1 series) expressing flagged WT and mutant forms of MKL1 were established: MCF-7/cont, MCF-7/MKL1 WT, MCF-7/MKL1 $\Delta$ N200, and MCF-7/MKL1 $\Delta$ N301. (panel A) After a 48-h treatment with tetracycline, total proteins from the MCF-7 sub-clones were immunoblotted for MKL1, flag, SRF, c-Fos, ER $\alpha$, and ERK. (panel B) The expression and subcellular localization of the flagged MKL1 forms and ER $\alpha$ were analyzed by immunofluorescence assays. (panel C) The fluorescence intensity of nuclear ER $\alpha$ was quantified on the entire population using Image-J software and normalized as a percentage of the control. (panel D) MCF-7/cont, MCF-7/MKL1-WT, MCF7/MKL1- $\Delta$ N200, and MCF-7/MKL1- $\Delta$ N301 cells were treated with $10 \mathrm{nM}$ E2 or vehicle in the 
1 presence of $2.5 \%$ dextran-treated charcoal-stripped FBS for $48 \mathrm{~h}$. The expression of several E2-

2 regulated genes after $10^{-8} \mathrm{M}$ E2 treatment was quantified using real-time PCR. For all data, the mean

3 values from at least three experiments \pm SEM are shown. Gray asterisks indicate significant

4 differences between the treated and untreated cells for each clone, whereas black asterisks indicate

5 significant differences between untreated clones $(* \mathrm{P}<0.05 ; * * \mathrm{P}<0.01 ; * * * \mathrm{P}<0.001)$.

6

7 Fig. 4: The expression of a constitutively active form of MKL1 in MCF-7 cells enhances growth

8 factor signaling and induces hormonal escape. (panel A) MCF-7/cont, MCF-7/MKL1-WT, MCF-

9 7/MKL1- $\mathrm{N} 200$, and MCF-7/MKL1- $\Delta \mathrm{N} 301$ cells (Clone 1 series) were treated with $10^{-8} \mathrm{M}$ E2 or vehicle in the presence of $2.5 \%$ dextran-treated charcoal-stripped FBS for $48 \mathrm{~h}$. The expression of several E2-regulated genes after E2 treatment was quantified using real-time PCR. The mean values

12 from at least three experiments \pm SEM are shown. Gray asterisks indicate significant differences 13 between treated and untreated cells for each clone whereas black asterisks indicate significant 14 differences between untreated clones ( ${ }^{*} \mathrm{P}<0.05 ; * * \mathrm{P}<0.01$; $\left.* * * \mathrm{P}<0.001\right)$. (panel $\left.\mathrm{B}\right)$ Western blot 15 analysis of p-Akt, Akt, p-ERK, and ERK expression in MCF-7 sub-clones. (panel C) The MCF-7 subclones were treated with $10^{-8} \mathrm{M}$ E2 or vehicle in the presence of $2.5 \%$ dextran-treated charcoalstripped FBS for $48 \mathrm{~h}$. Flow cytometry experiments were performed to determine the percentages of cells in each cell cycle phase. The data are the mean values from triplicate experiments \pm SEM. (panel D) MCF-7 sub-clones were treated with $10^{-8} \mathrm{M} \mathrm{E2}$ or vehicle in the presence of $2.5 \%$ dextran-treated charcoal-stripped FBS for 3 or 5 days. The cells were then counted manually upon trypsinization. The data are the mean values from triplicate experiments \pm SEM. Asterisks indicate significant differences in the fold increases in cell numbers upon $\mathrm{E} 2$ treatment between clones $\left({ }^{*} \mathrm{P}<0.05 ;{ }^{*} \mathrm{P}<0.01\right.$; $* * * \mathrm{P}<0.001)$.

Fig. 5: MKL1 modulates the MCF-7 response to 4-hydoxytamoxifene (4OHT). MCF-7/cont, MCF7/MKL1 WT, MCF-7/MKL1 $\Delta$ N200, and MCF-7/MKL1- $\Delta$ N301 cells (Clone 1 series) were treated or not with $1 \mu \mathrm{M} 4 \mathrm{OHT}$ in the presence of 5\% FBS (containing estrogens) for $48 \mathrm{~h}$. (panel A) Flow 
1 (panel B) The expression of several E2-regulated genes after 4OHT treatment was quantified using 2 real-time PCR. The mean values from at least three experiments \pm SEM are shown. Gray asterisks 3 indicate significant differences between the treated and untreated cells for each clone, whereas black

4 asterisks indicate significant differences between untreated clones. $\left({ }^{*} \mathrm{P}<0.05\right.$; $\left.{ }^{*} \mathrm{P}<0.01 ; * * * \mathrm{P}<0.001\right)$ 
Figure 1:

A

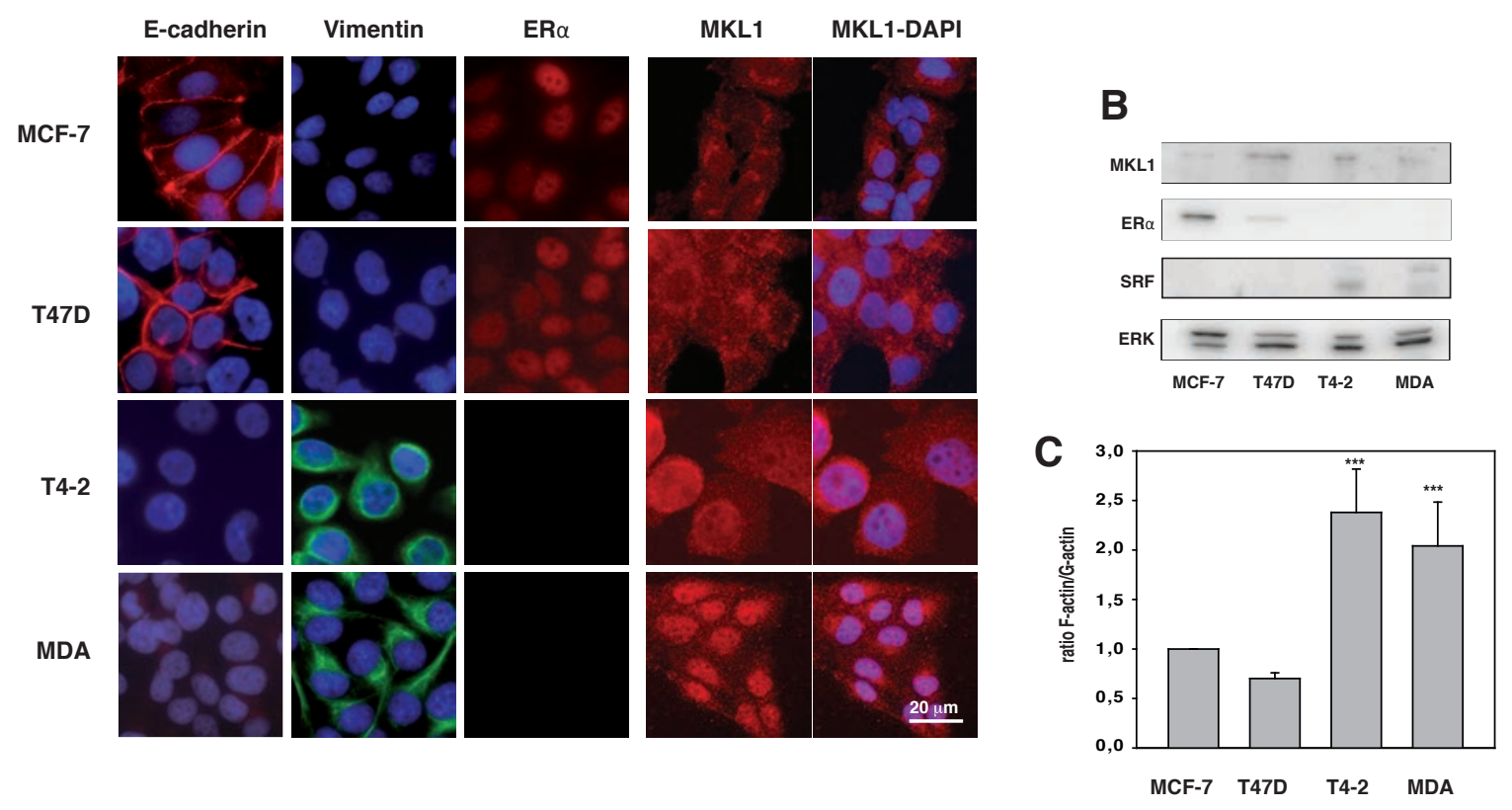

D

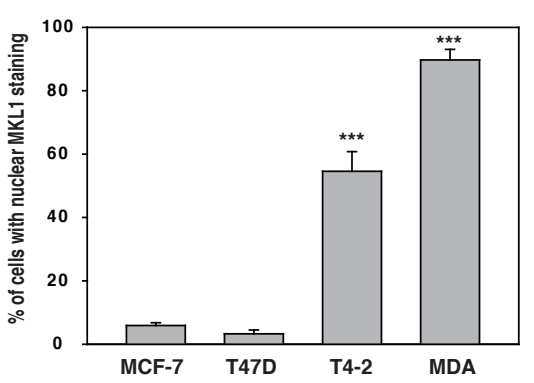

E

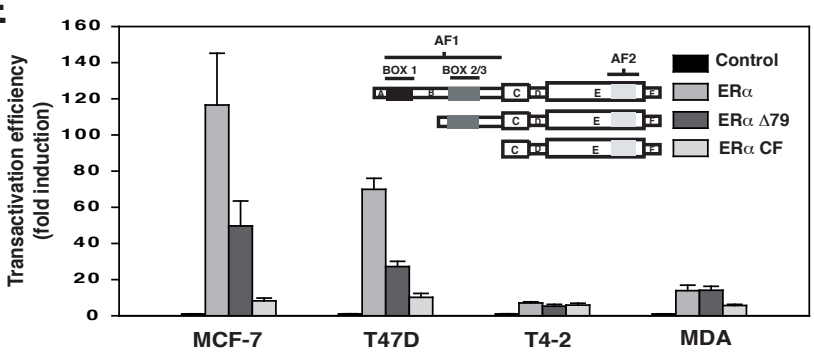

\section{F}
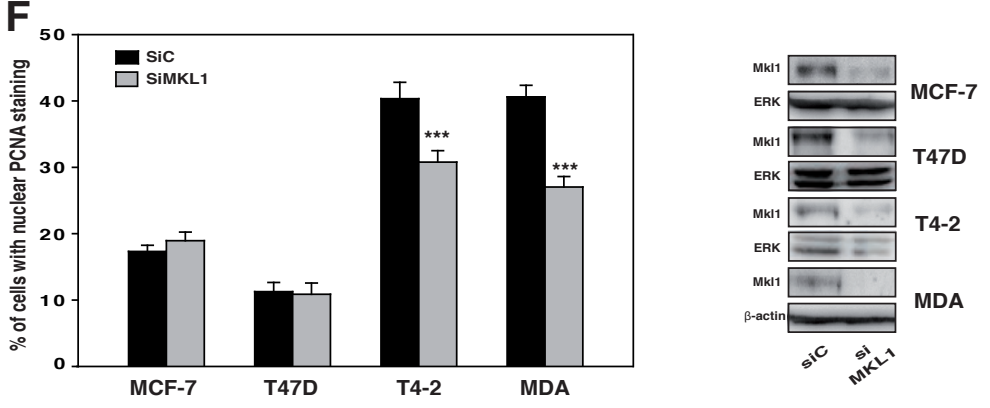
Figure 2:

A

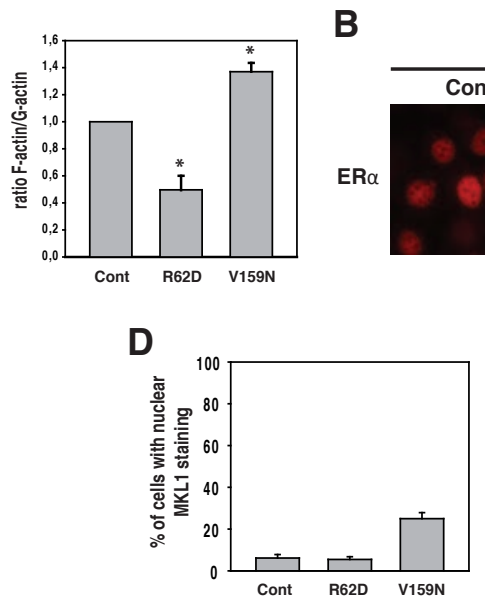

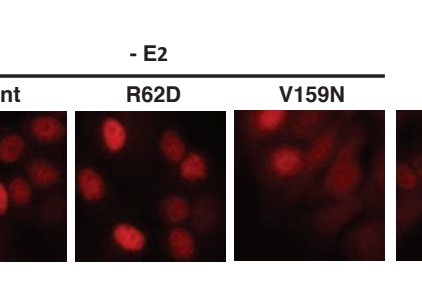
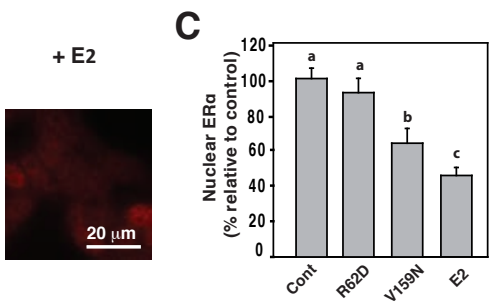

E
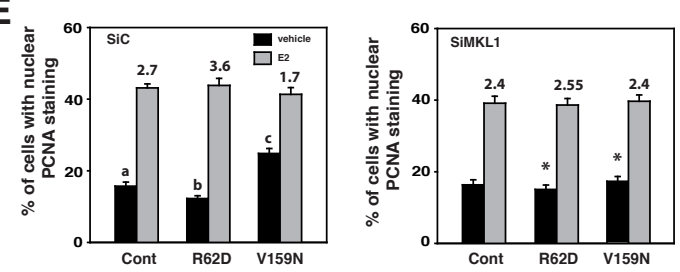
Figure 3:

A

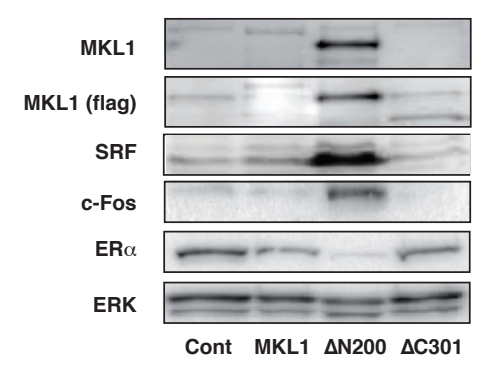

C

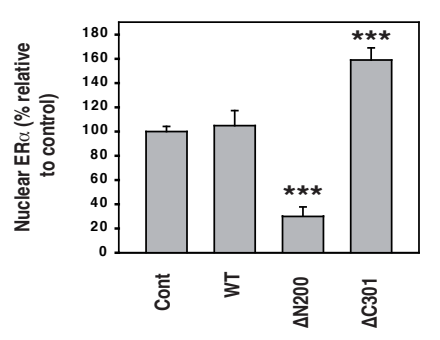

\section{B}

ER $\alpha$
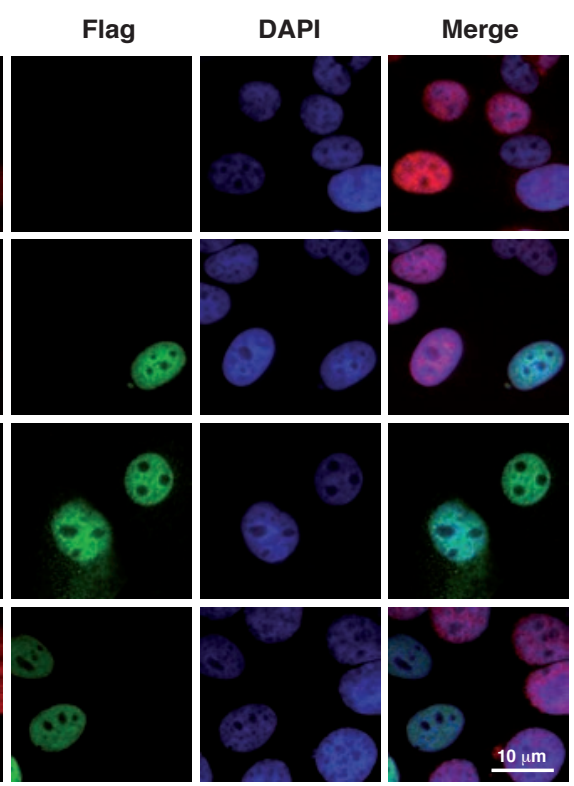

D
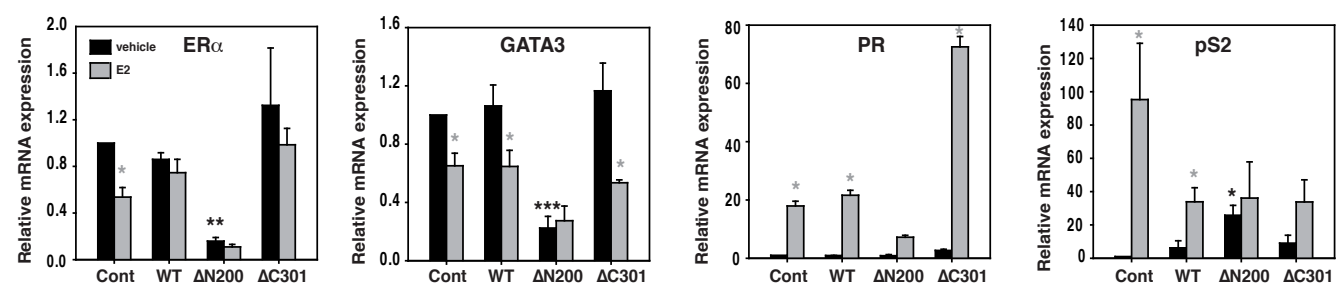
Figure 4:

A
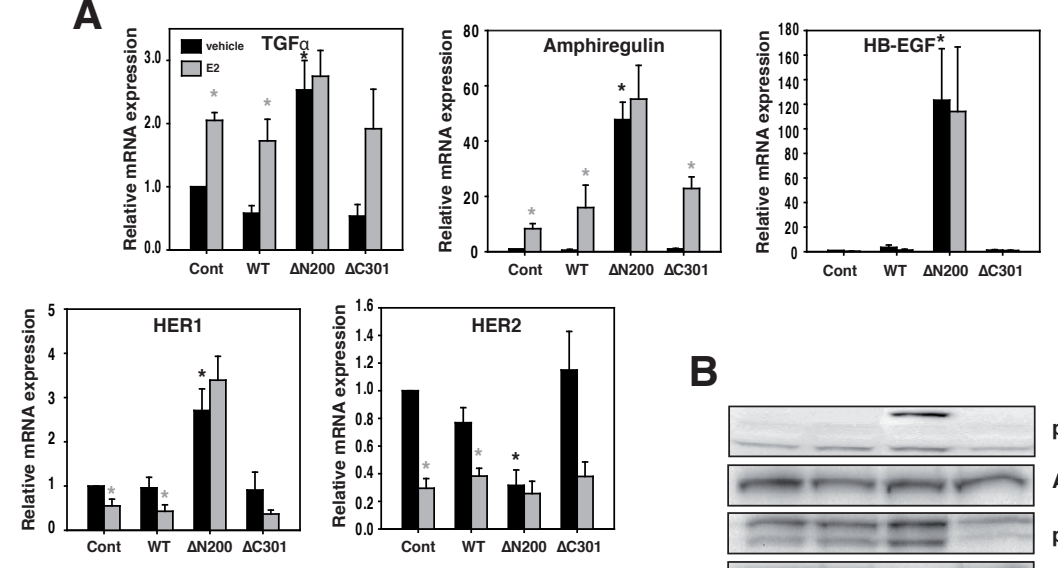

B
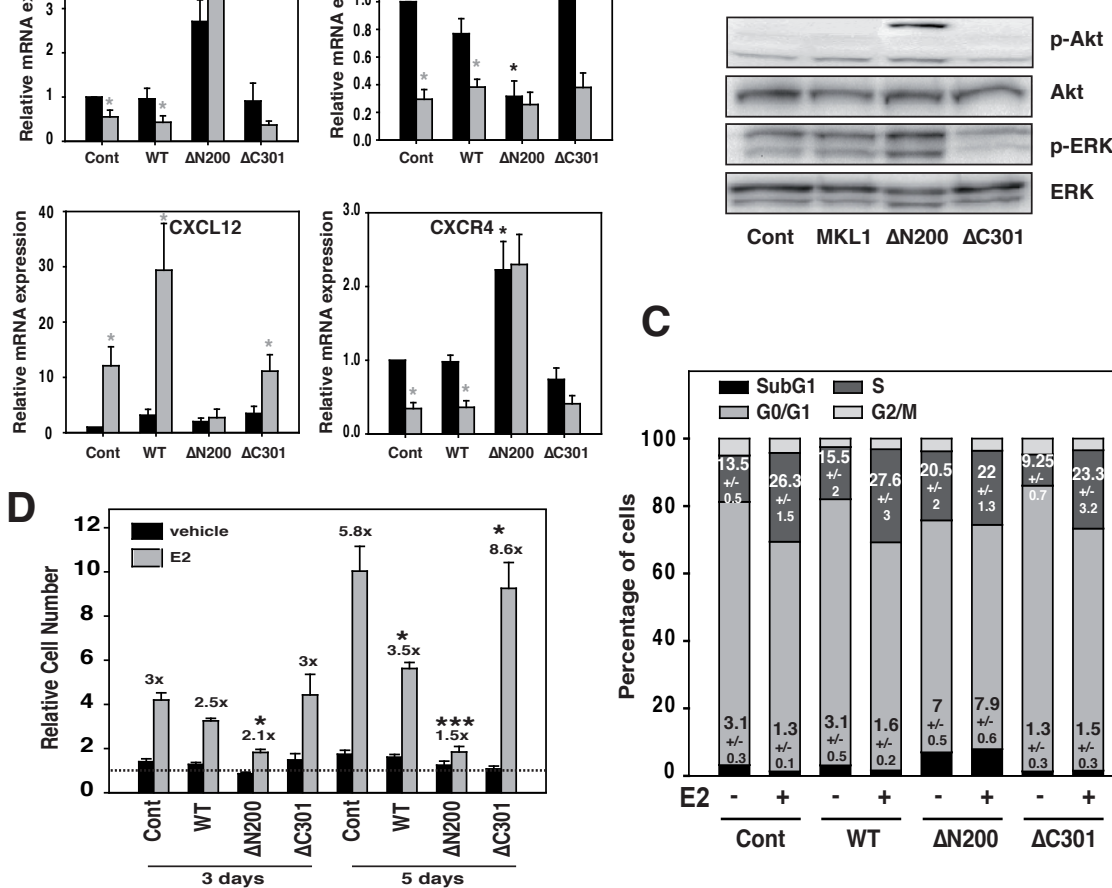

C

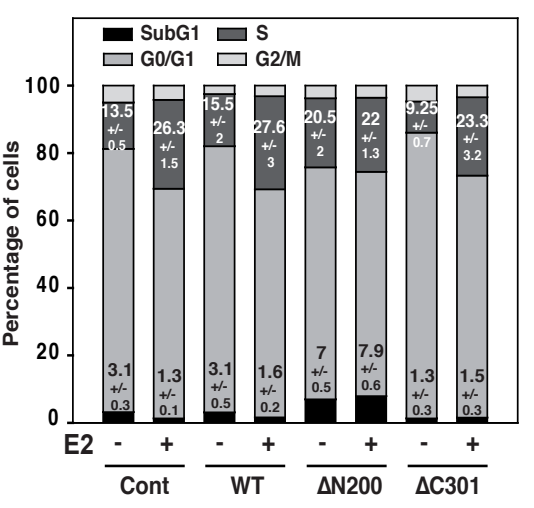


Figure 5:
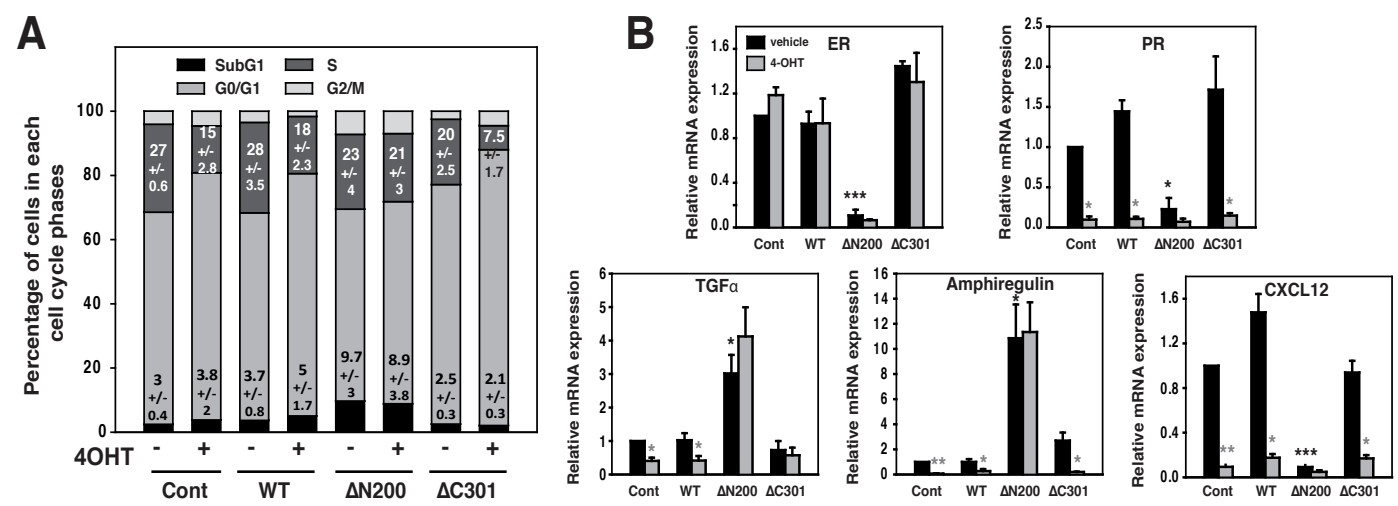
Title: Activation of MKL1/actin signaling pathway induces hormonal escape of estrogen-responsive breast cancer cell lines.

Authors: Gwenneg Kerdivel ${ }^{1}$, Antoine Boudot ${ }^{1}$, Denis Habauzit ${ }^{1}$, Frederic Percevault ${ }^{1}$, Florence Demay $^{1}$, Farzad Pakdel ${ }^{1}$, Gilles Flouriot ${ }^{1 *}$

\section{Supplementary Figure S1}

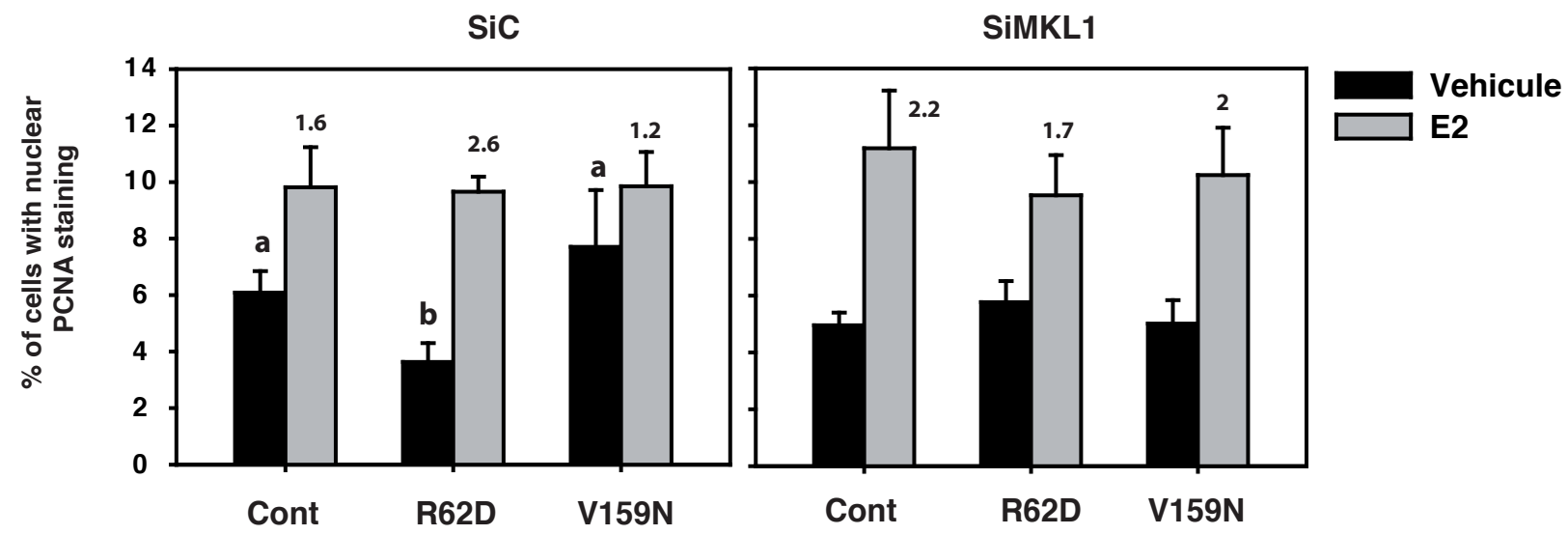

Fig. S1. T47D cell proliferation is regulated by actin dynamic through MKL1. T47D cells were transfected with siRNA targeting MKL1 or with control siRNA and 24 hours later with actin mutant (R62D, V159N) expression vectors. 16 hours after, cells were treated during $48 \mathrm{~h}$ with $10^{-8} \mathrm{M}$ E2 or vehicle in presence of $2.5 \%$ dextran-treated charcoal stripped FBS. PCNA staining was visualized by immunofluorescence and the percentage of cells in S phase was determined. Mean values from three experiments \pm SEM are shown. Significant differences $(\mathrm{P}<0.05)$ are indicated by different lowercase letters. E2 fold inductions are indicated. 


\section{Supplementary Figure S2}

A

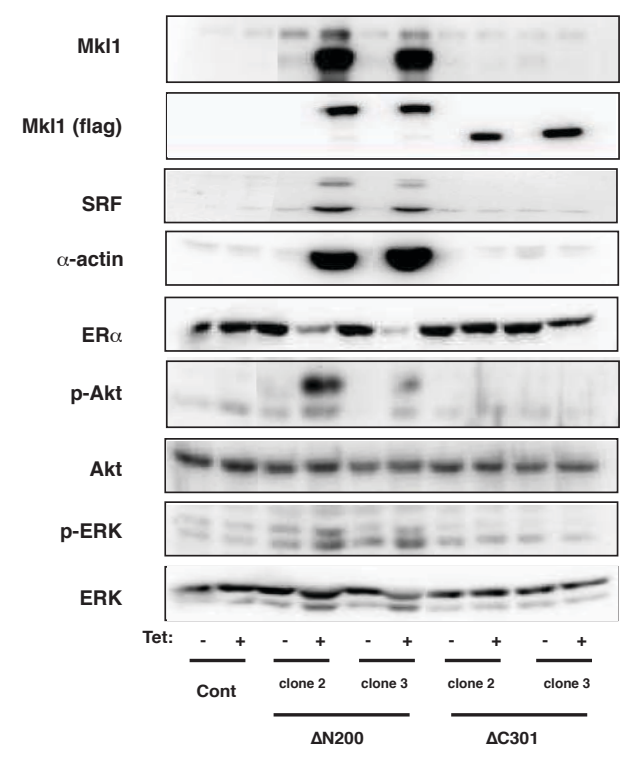

C
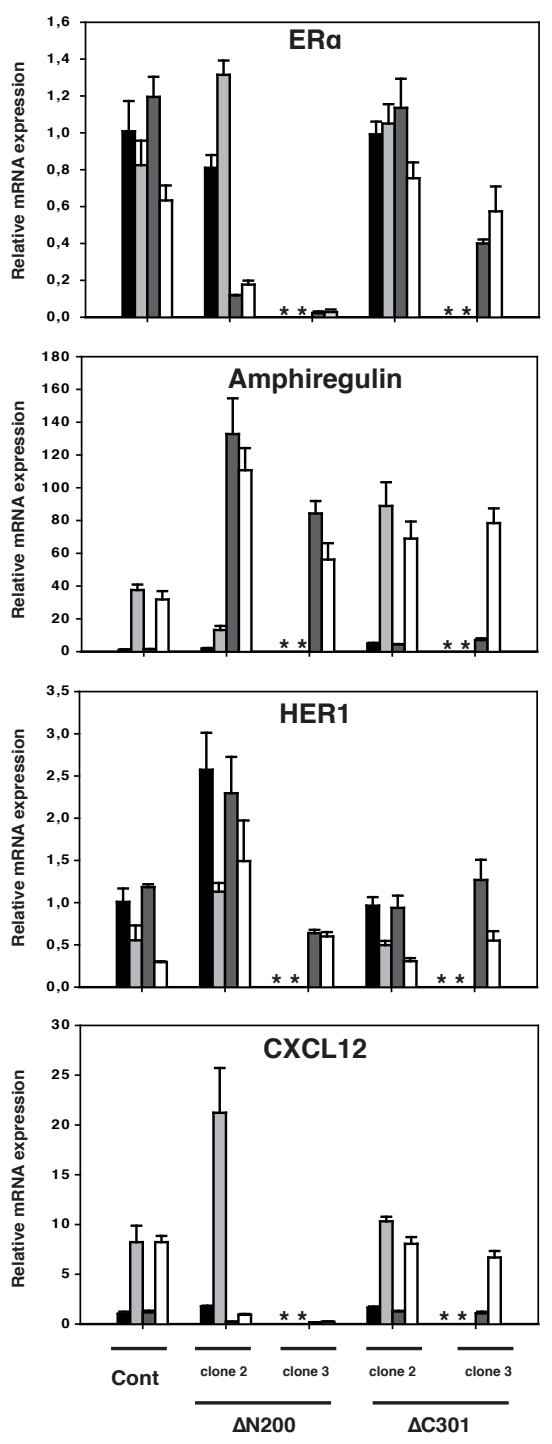

B
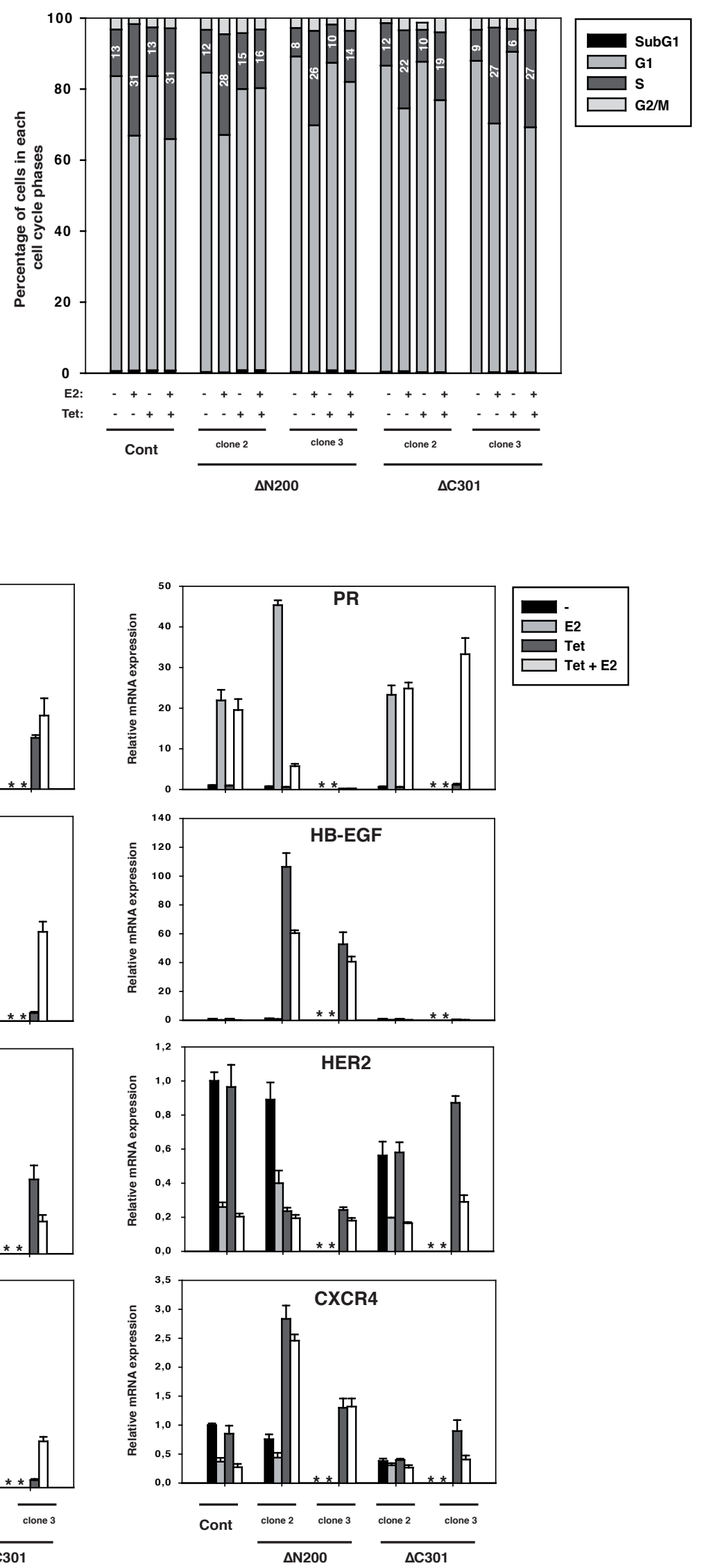
Fig. S2. Constitutively active form of MKL1 impairs estrogenic response in MCF-7 cells. Two other series of clones (Clone 2 and 3) expressing flagged mutant forms of MKL1 were established. (panel A) After a $48 \mathrm{~h}$ treatment with tetracyclin, total proteins from MCF-7 sub-clones were immunoblotted for MKL1, flag, SRF, $\alpha$-actin, ER $\alpha$, p-Akt, Akt, p-ERK and ERK. (panel B) MCF-7 sub-clones were treated or not with $10^{-8} \mathrm{M} \mathrm{E} 2$ and tetracyclin in presence of $2.5 \%$ dextran-treated charcoal stripped FBS for $48 \mathrm{~h}$. Flow cytometry experiments were realized to determine percentages of cells in each cell cycle phase. (panel C) Clone 2 and 3 series were treated or not with $10^{-8} \mathrm{M}$ E2 and tetracyclin in presence of $2.5 \%$ dextran-treated charcoal stripped FBS for $48 \mathrm{~h}$. Expression of several E2-regulated genes then was quantified using real-time PCR. Mean values from three independent experiments \pm SEM are shown. Asterisks indicate not determined values.

\section{Supplementary Figure S3}

A
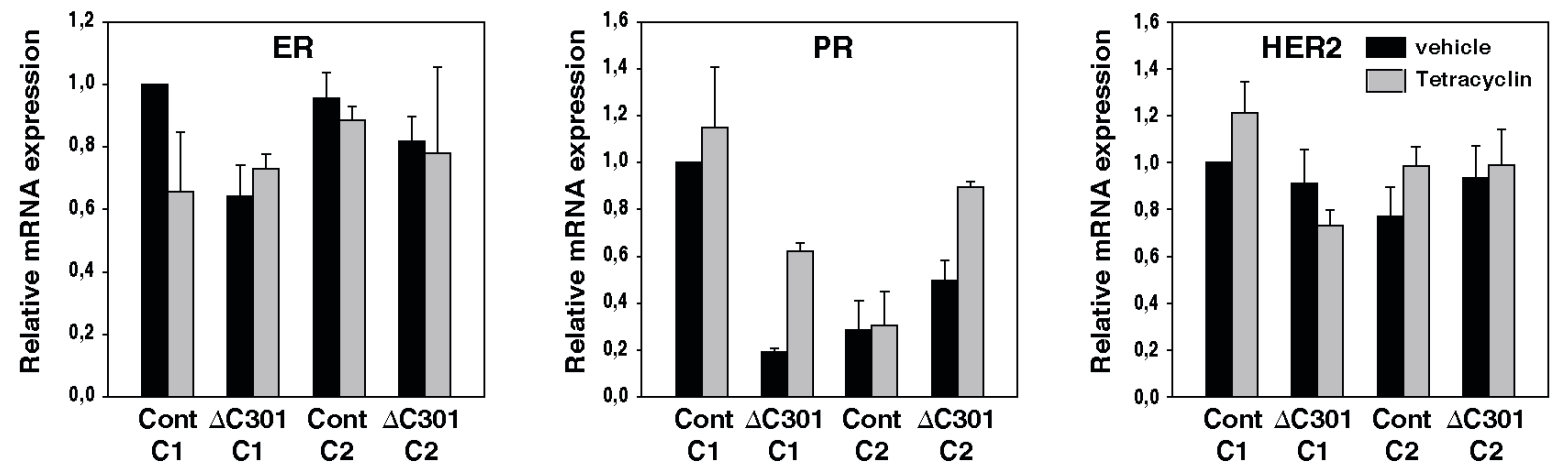

B

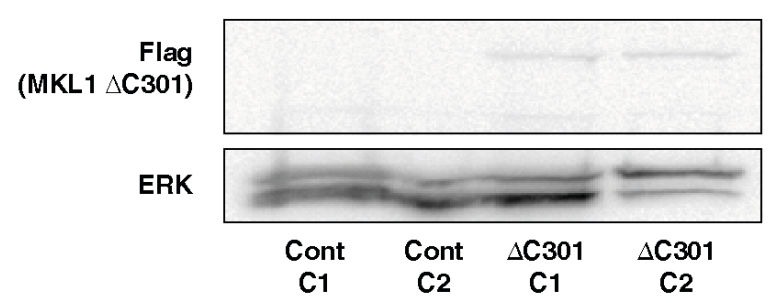

Fig. S3. Expression of the dominant negative MKL1 C301 in ER-negative MDA-MB231 cells fails to restore ER $\alpha$, PR and HER-2 expression. MDA-MB231 sub-clones expressing flagged $\Delta \mathrm{C} 301$ mutant form of MKL1 were established: two MDA-MB231/cont clones (C1 and C2), and two MDAMB231/MKL1 $\Delta$ C301 clones (C1 and C2) were obtained. (panel A) After a 48h treatment with 
tetracycline or vehicle, expression of ER $\alpha$, PR and HER2 was quantified using real-time PCR. Mean values from two experiments \pm SEM are shown. (panel B)Total proteins from MDA-MB231 subclones were immunoblotted for flag and ERK. 